\title{
1 Cbln1 regulates axon growth and guidance in multiple neural regions
}

2

3

4

5 Peng $\operatorname{Han}^{1, \dagger}$, Yuanchu She ${ }^{1, \dagger}$, Zhuoxuan Yang ${ }^{1}$, Mengru Zhuang $^{1}$, Qingjun Wang ${ }^{1}$, Xiaopeng Luo ${ }^{1}$,

6 Chaoqun $\mathrm{Yin}^{1}$, Junda $\mathrm{Zhu}^{1}$, Samie R. Jaffrey ${ }^{2 *}$, Sheng-Jian $\mathrm{Ji}^{1 *}$

7

$8 \quad{ }^{1}$ School of Life Sciences, Department of Biology, Shenzhen Key Laboratory of Gene Regulation and

*For correspondence: sri2003@med.cornell.edu; jisj@SUSTech.edu.cn 


\section{Abstract}

The accurate construction of neural circuits requires the precise control of axon growth and guidance, which is regulated by multiple growth and guidance cues during early nervous system development. It is generally thought that the growth and guidance cues that control the major steps of axon guidance have been defined. Here, we describe cerebellin-1 (Cbln1) as a novel cue that controls diverse aspects of axon growth and guidance throughout the central nervous system (CNS). Cbln1 has previously been shown to function in late neural development to influence synapse organization. Here we find that Cbln1 has an essential role in early neural development. Cbln1 is expressed on the axons and growth cones of developing commissural neurons and functions in an autocrine manner to promote axon growth. Cbln1 is also expressed in intermediate target tissues and functions as an attractive guidance cue. We find that these functions of Cbln1 are mediated by neurexin-2 (Nrxn2), which functions as the Cbln1 receptor for axon growth and guidance. In addition to the developing spinal cord, we further show that Cbln1 functions in diverse parts of the CNS with major roles in cerebellar parallel fiber growth and retinal ganglion cell axon guidance. Despite the prevailing role of Cbln1 as a synaptic organizer, our study discovers a new and unexpected function for $\mathrm{Cb} \ln 1$ as a general axon growth and guidance cue throughout the nervous system.

\section{Impact statement}

Despite the prevailing role of Cbln1 as a synaptic organizer, our study discovers a new and unexpected function for $\mathrm{Cb} \ln 1$ as a general axon growth and guidance cue throughout the nervous system.

Keywords: Cbln1, axon guidance, commissural axon, floor plate, cerebellum, optic chiasm 


\section{Introduction}

The precise control of axon pathfinding is critical for the correct neural wiring during nervous system development. The stimulation of axon growth and regulation of axon guidance have been shown to require adhesion molecules, diffusible signals and morphogens such as Netrins (Moreno-Bravo et al. 2019; Wu et al. 2019), Slits (Brose et al. 1999; Kidd et al. 1999; Zou et al. 2000), Ephrins (Paixao et al. 2013), Semaphorins (Zou et al. 2000; Nawabi et al. 2010), Draxin (Islam et al. 2009), Shh (Okada et al. 2006), Whts (Lyuksyutova et al. 2003), and BMPs (Augsburger et al. 1999; Butler and Dodd 2003). These axon guidance molecules bind to their receptors in the axon growth cones to activate various signaling pathways that eventually change the cytoskeleton (McCormick and Gupton 2020). The lack of newly identified cues in the past decade has suggested that the major classes of growth and guidance cues have now been identified.

The commissures in the rodent spinal cord are one of the most prominent model systems to study axon growth and guidance. In a search for the differentially expressed genes in the dorsal spinal cord of mouse embryos, we identified a gene encoding the secreted protein cerebellin-1 (Cbln1). Cbln1 is released from cerebellar parallel fibers and has previously been characterized as a synaptic organizer by forming the synapse-spanning tripartite complex Nrxn-Cbln1-GluD2 (Nrxn, neurexin; GluD2, the ionotropic glutamate receptor family member delta-2) (Yuzaki 2018; Suzuki et al. 2020). However, whether Cbln1 is expressed and plays roles in earlier nervous system development is unknown.

Here we found that Cbln1 is expressed both in the dorsal commissural neurons (DCN) and in the floor plate (FP) of the embryonic mouse spinal cord. We generated DCN- and FP-specific Cbln1 conditional knockout (cKO) mice which demonstrated that the cell-autonomous and non-cellautonomous CbIn1 from DCNs and FP regulate commissural axon growth and guidance, respectively. The dual roles of Cbln1 are mediated by its receptor, neurexin-2. Interestingly, the functions and mechanisms of Cbln1 in regulating axon growth and guidance were replicated in the developing cerebellar granule axon growth and the embryonic retinal ganglion cell axon guidance, respectively. 
Together, our findings reveal a general role for Cbln1 in regulating axon growth and guidance during early nervous system development prior to synapse formation.

\section{Results}

\section{Cbln1 is expressed in both dorsal commissural neurons and floor plate in the developing mouse} spinal cord

To identify the differentially expressed genes in the mouse embryonic dorsal spinal cord, we genetically labeled embryonic dorsal spinal neurons with eGFP by crossing Wnt1-cre (Danielian et al. 1998; Charron et al. 2003) with Rosa26mTmG (Muzumdar et al. 2007) mice (Figure 1-figure supplement 1A). Mouse embryonic E10.5, E11.5 and E12.5 spinal cords were dissected, and dorsal spinal neurons were collected (Figure 1-figure supplement $1 B$ ). Then $\mathrm{GFP}^{+}$dorsal spinal neurons were purified by fluorescence-activated cell sorting (FACS) and the differentially expressed genes (DEGs) during the developmental stages were identified by the expression profiling analysis using microarray analysis (Figure 1-figure supplement 1C and Supplementary file 1). We carried out in situ hybridization to further explore the expression patterns of the candidate DEGs in the developing spinal cord. Among the candidates, $C b / n 1$ was notable due to its expression pattern. $C b / n 1$ has strong signals in floor plate (FP) and weak signals in dorsal commissural neurons (DCNs) at E10.5 (Figure 1A). At E11.5 and E12.5, the expression of Cbln1 increases in DCNs (notice DCNs migrate ventrally and medially at E12.5), maintains a high level in FP, and also appears in subpopulations of motor neurons (Figure 1A).

To further explore the expression patterns of $\mathrm{Cb} \ln 1$ protein and confirm its expression sites, we carried out immunofluorescence (IF) using a Cbln1 antibody (Muguruma et al. 2010). Coimmunostaining of Cbln1 with Lhx2, a DCN marker (Wilson et al. 2008), confirmed the expression of Cbln1 in DCNs of developing spinal cords from E10.5 to E12.5 (Figure 1B-D). Expression of Cbln1 in FP was also confirmed by co-immunostaining with the FP marker Alcam (Figure 1B-D). To validate the 
bioRxiv preprint doi: https://doi org/10.1101/2021.11.16.468844; this version posted November 16,2021 . The copyright holder for this preprint (which was not certified by peer review) is the author/funder, who has granted bioRxiv a license to display the preprint in perpetuity. It is made available under aCC-BY 4.0 International license.

specificity of Cbln1 expression in FP, we used a spinal floor plate-deficient model, Gli2 knockout (KO) mouse (Bai and Joyner 2001). As shown in Figure 1-figure supplement 1D, IF signal of Cbln1 in Alcam-marked FP was gone in Gli2 KO. These results revealed an interesting expression pattern for Cbln1 that is expressed both in the dorsal commissural neurons (DCNs) and in the intermediate target for DCNs, the floor plate.

\section{Cell-autonomous Cbln1 in the dorsal commissural neurons stimulates commissural axon growth in}

\section{an autocrine manner}

Next, we wanted to explore the roles of Cbln1 expressed in DCNs and floor plate, separately. In order to specifically ablate $C b / n 1$ from these tissues, we generated conditional knockouts (cKO) of Cbln1 using tissue-specific Cre lines (Figure 2-figure supplement 1A). We used Wnt1-Cre line to specifically ablate $C b / n 1$ from spinal DCNs, without affecting $C b / n 1$ expression in other parts of spinal cord (Figure 2A). Cbln1 cKO in spinal DCNs does not disturb neurogenesis of these neurons, as indicated by normal numbers, distribution and patterning of $\operatorname{Lh} \times 2^{+}$and $\operatorname{Lh} \times 9^{+}$interneurons in the developing spinal cord (Figure 2-figure supplement 1B-D). We continued to check commissural axon (CA) growth in DCN-specific Cbln1 cKO. We prepared open-books of developing spinal cords and used Robo3 immunostaining to label commissural axons. Robo3 selectively marks commissural axons as they navigate to and across the floor plate (Sabatier et al. 2004). As shown in Figure 2B-D, both lengths and numbers of commissural axons were decreased in Cbln1 cKO embryos compared with their littermate controls. These data suggest that Cbln1 in the dorsal commissural neurons is required for their own commissural axon growth.

To further test whether Cbln1 is sufficient to stimulate commissural axon growth in vivo, we used a model of chick neural tube. Chick $C b \ln 1(c C b / n 1)$ is expressed in the dorsal commissural neurons (DCN) of developing chick neural tube, as is the case with mouse $C b \ln 1$, but is not detected in the floor plate of chick embryonic spinal cord (Figure 2-figure supplement 1E). We made a DCNspecific overexpression plasmid, pMath1-eGFP-IRES-MCS, by modifying a DCN-specific knockdown 
bioRxiv preprint doi: https://doi org/10.1101/2021.1116.468844; this version posted November 16,2021 . The copyright holder for this preprint (which was not certified by peer review) is the author/funder, who has granted bioRxiv a license to display the preprint in perpetuity. It is made available under aCC-BY 4.0 International license.

plasmid pMath1-eGFP-miRNA (Wilson and Stoeckli 2013). Unilateral DCN-specific overexpression of cCbln1 by in ovo electroporation of pMath1-eGFP-IRES-cCbln1 enhanced chick commissural axon growth compared with control plasmid without changing commissural neuron numbers (Figure 2E-G). These data suggest that $\mathrm{Cb} \ln 1$ is sufficient to stimulate commissural axon growth.

Next, we continued to elucidate the mechanisms for the cell-autonomous functions of Cbln1. We hypothesized that Cbln1 was secreted from the dorsal commissural neurons (DCN) and then acted to stimulate commissural axon growth in an autocrine manner. To test this, we cultured DCN explants from E10.5 (a stage when most commissural axons have not projected to the midline yet and are called pre-crossing axons) mouse spinal cords and used Tag1 immunostaining to visualize pre-crossing commissural axons. Tag1 has been widely used as a marker for pre-crossing commissural axons (Chen et al. 2008; Colak et al. 2013). Compared with control embryonic DCN explants, the commissural axon growth of Wnt1-Cre-mediated Cbln1 cKO DCNs was significantly inhibited, indicated by decreased axon numbers and reduced axon lengths (Figure $3 A-C$ ), which is consistent with in vivo results for DCN-specific Cbln1 cKO (Figure 2B-D). These axon growth defects were efficiently rescued by adding a recombinant human Cbln1 protein ( $r h \mathrm{Cb} \mid n 1)$ to the cultures (Figure $3 A-C$ ). These data suggest that the cell-autonomous $\mathrm{Cb} \ln 1$ regulates commissural axon growth in an autocrine manner.

We next asked whether Cbln1-induced axonal growth works locally in commissural axons and growth cones. Immunofluorescence of DCN neuron culture using a Cbln1 antibody detected robust Cbln1 IF signals in commissural axons and growth cones (Figure 3D). To confirm the specificity of these axonal Cbln1 IF signals, we generated lentiviral shCbln1 which led to dramatic knockdown of Cbln1 in cultured neurons (Figure 3-figure supplement $1 A$ ). The Cbln1 IF signals in commissural axons and growth cones were largely lost after knockdown of Cbln1 (Figure 3D,E), indicating that Cbln1 is present in commissural axons and growth cones.

To test whether Cbln1 is exocytosed from axons, we applied glycyl-L-phenylalanine 2naphthylamide (GPN) to the DCN cultures. GPN can be specifically cleaved by cathepsin C, which 
bioRxiv preprint doi: https://doi org/10.1101/2021.11.16.468844; this version posted November 16,2021 . The copyright holder for this preprint (which was not certified by peer review) is the author/funder, who has granted bioRxiv a license to display the preprint in perpetuity. It is made available under aCC-BY 4.0 International license.

147 leads to targeted disruption of the lysosomal membrane (Padamsey et al. 2017; Ibata et al. 2019).

148 Treatment of DCN cultures with GPN, followed by an IF protocol to detect surface Cbln1 by leaving out the permeabilization steps, showed a loss of Cbln1 IF signals on the commissural axon surface (Figure $3 F, G)$, suggesting that $C b \ln 1$ is released from lysosomes in commissural axons and growth cones. Blocking Cbln1 secretion by GPN inhibited commissural axon growth (Figure $3 \mathrm{H}$ ), further supporting a model that Cbln1 is released from and works back on commissural axon and growth cones to stimulate axon growth.

The facts that the secreted Cbln1 works extrinsically and that it is expressed in the floor plate (FP) mouse Cbln1. High levels of Cbln1 were detected in the culture media, indicating the overexpressed Cbln1 was secreted from COS7 cells (Figure 4-figure supplement 1A). We then co-cultured the dorsal spinal cord explants from E11 mouse embryos with COS7 cell aggregates expressing Cbln1 tagged with FLAG and GFP or GFP alone in collagen gels (Figure 4A). The dorsal spinal cord explants growing with Cbln1-expressing COS7 cell aggregates had significantly longer axons than the control (Figure $4 A, B)$. More importantly, the growth of commissural axons was attracted toward Cbln1expressing COS7 cell aggregates, indicated by the higher axon number ratios (Proximal/Distal) compared with the control cell aggregates expressing GFP alone (Figure $4 A, C$ ). These results suggest that the non-cell-autonomous Cbln1 functions as an attractive axon guidance molecule. specific Cbln1 cKO mice. We utilized Foxa2-Cre ${ }^{E R T}$ line which has been used to induce Cre 170 recombinase expression specifically in floor plate cells in response to tamoxifen (TM) treatment

171 (Park et al. 2008; Hernandez-Enriquez et al. 2015). Cbln1 expression was specifically ablated from 172 the floor plate in these cKO embryos, without affecting its expression in other parts of spinal cord 
bioRxiv preprint doi: https://doi org/10.1101/2021.11.16.468844; this version posted November 16,2021 . The copyright holder for this preprint (which was not certified by peer review) is the author/funder, who has granted bioRxiv a license to display the preprint in perpetuity. It is made available under aCC-BY 4.0 International license.

173 including the dorsal commissural neurons (DCNs) (Figure 4D). The neural patterning or neurogenesis

174 was not disturbed by ablation of Cbln1 from the floor plate (FP) (Figure 4-figure supplement 1B-E).

175 However, examination of commissural axon trajectories using Tag1 immunostaining in E11.5 spinal

176 cords revealed significant axon guidance defects in the midline and ventral spinal cord. First, the

177 thickness of the ventral commissure (VC) was significantly reduced in the FP-specific Cbln1 cKO

178 embryos compared with their littermate controls (Figure $4 E, F$ ). Second, the intersection of the main

179 commissural axon bundle with the ventral commissural funiculus was shifted laterally in the FP-

180

181 specific CbIn1 cKO embryos compared with their littermate controls (Figure 4E). The distances between the point of intersection and the midline were quantified, showing a significant increase in the FP-specific CbIn1 cKO embryos (Figure 4G). These phenotypes were also evident by NFM immunostaining (Figure 4-figure supplement $1 F-H$ ). These axon guidance defects suggest that Cbln1 from the floor plate indeed works as an axon guidance cue in the developing spinal cord.

To observe more clearly the commissural axon guidance behaviors in the FP-specific Cbln1 cKO embryos, we performed Dil labeling of DCNs in the open-book spinal cords at E11.5. As shown in Figure $4 H, I$, there was a significant decrease of the number of normal crossing commissural axons in the $C b \ln 1$ cKO. Meanwhile, the numbers of commissural axons showing guidance defects such as ipsilateral turning, slower growing or winding crossing were significantly increased in Cb/n1 cKO embryos compared with their littermate controls (Figure $4 H, I)$.

All these data support the idea that the non-cell-autonomous Cbln1 derived from the floor plate works as an axon guidance cue for commissural axons in the developing spinal cord.

\section{Nrxn2 is expressed in the developing dorsal commissural neurons and axons, and mediates Cbln1-}

\section{induced axon growth and guidance as its receptor}

Previously Cbln1 was shown to work as a synaptic organizer for the cerebellar excitatory PF-PC (PF, parallel fibers; PC, Purkinje cells) synapses by binding to its presynaptic receptor, neurexin (Nrxn) and its postsynaptic receptor, glutamate receptor delta 2 (GluD2) (Matsuda et al. 2010; Uemura et al. 
bioRxiv preprint doi: https://doi org/10.1101/2021.1116.468844; this version posted November 16,2021 . The copyright holder for this preprint (which was not certified by peer review) is the author/funder, who has granted bioRxiv a license to display the preprint in perpetuity. It is made available under aCC-BY 4.0 International license.

2010). In addition, trans-synaptic signaling through Nrxn-Cbln-GluD1 has also been shown to mediate the inhibitory synapse formation in cortical neurons (Yasumura et al. 2012; Fossati et al. 2019). Here we wondered whether Nrxn, GluD1, and/or GluD2 work as receptors for Cbln1 to mediate its regulation of commissural axon growth and guidance in the developing spinal cord. To test this, we first checked if Nrxn, GluD1, and GluD2 are expressed in developing dorsal commissural neurons (DCNs) or not. GluD1 or GluD2 mRNA was not detected in E11.5 spinal cords (Figure 5-figure supplement 1A). There are three Nrxn genes in the mammalian genome, each of them encoding two major protein isoforms, $\alpha$-neurexin and $\beta$-neurexin (Reissner et al. 2013). Although Nrxn1, 2 and 3 mRNAs were all detected in E11.5 spinal cords, only Nrxn2 mRNA was found to be expressed in DCNs (Figure 5A). We further detected both $N r \times n 2 \alpha$ and $N r \times n 2 \beta$ mRNAs in DCNs using the isoform-specific probes (Figure 5B). Immunostaining using an Nrxn2 antibody detected robust Nrxn2 IF signals in commissural axons and growth cones (Figure $5 C, D$ ), making it possible that Nrxn2 works as the receptor for Cbln1 in developing commissural axons. Indeed, commissural axon lengths were significantly decreased after knocking down either pan-Nrxn2 or Nrxn2 $\alpha, \mathrm{Nrxn} 2 \beta$ separately (Figure 5-figure supplement $1 B-D$, and Figure $5 E, F)$, suggesting that Nrxn2 mediates cell-autonomousCbln1-induced commissural axon growth. We continued to test whether Nrxn2 also mediates the non-cell-autonomous function of Cbln1 to attract commissural axon turning. As shown in Figure 5G, Cbln1-expressing cell aggregates failed to attract commissural axons of DCN neurons which were knocked down of either pan-Nrxn2 or Nrxn2 $\alpha, \operatorname{Nrxn} 2 \beta$ separately. These data suggest that Nrxn2 (both Nrxn2 $\alpha$ and Nrxn2 $\beta$ ) works as the receptor for $\mathrm{Cbln} 1$ to mediate its cell-autonomous function in axon growth and non-cell-autonomous function in axon guidance of commissural neurons in the developing spinal cord.

In summary, these data and findings support the following working model for $\mathrm{Cb} \ln 1$ in the developing spinal cord (Figure 5-figure supplement 1E,F). In the pre-crossing commissural axons, Cbln1 is expressed cell-autonomously by the dorsal commissural neurons (DCN) and axons. Commissural axon growth cone-secreted $\mathrm{Cbln} 1$ binds to $\mathrm{Nrxn} 2$ receptors in commissural axons and 
bioRxiv preprint doi: https://doi org/10.1101/2021.11.16.468844; this version posted November 16,2021 . The copyright holder for this preprint (which was not certified by peer review) is the author/funder, who has granted bioRxiv a license to display the preprint in perpetuity. It is made available under aCC-BY 4.0 International license.

growth cones to stimulate commissural axon growth in an autocrine manner (Figure 5-figure supplement $1 E)$. In the DCN-specific Cbln1 cKO embryos, commissural axon growth is reduced compared with their littermate controls (Figure 5-figure supplement 1E). When commissural axons approach the midline, the floor plate-derived Cbln1 attracts commissural axons to the midline which is also mediate by Nrxn2 receptors (Figure 5-figure supplement 1 F). In the floor plate-specific Cbln1 cKO embryos, commissural axon guidance in the midline crossing is impaired, resulting in a U-shaped and thinner ventral commissure compared with the V-shaped and thick ventral commissures in the littermate control embryos (Figure 5-figure supplement 1F).

\section{Cell-autonomous Cbln1 from cerebellar granular cells is required for parallel fiber growth}

We wondered whether the function of $\mathrm{Cbln} 1$ to regulate axon development is a general mechanism which also works in other brain regions during development. The studies on Cbln1 so far have been focused on its functions as a synaptic organizer in cerebellum. Whether Cbln1 is expressed and exerts its functions at earlier stages of cerebellar development remains unexplored. We first checked expression of Cbln1 in earlier cerebellar development. As shown in Figure 6A, high and specific Cbln1 expression was detected in the P4-P8 cerebellar granule cells in the inner granule layer (IGL) by in situ hybridization. Immunofluorescence using a Cbln1 antibody showed that Cbln1 protein is enriched in the molecular layer (ML) of cerebellum (Figure 6B), suggesting that $\mathrm{Cb} \ln 1$ protein is expressed and secreted by cerebellar granule cell (GC) axons.

Next we tested the possible roles of Cbln1 in earlier cerebellar development. We generated Cbln1 cKO in cerebellum using the Wnt1-cre line (Danielian et al. 1998; Cerrato et al. 2018), which resulted in the efficient knockout of Cbln1 from GCs (Figure 6C). Axon growth rates of Cbln1-deficient GCs in vitro were significantly decreased compared with control neurons (Figure 6D,E), suggesting that the cell-autonomous Cbln1 is required for GC axon growth. Similar to Cbln1 on commissural axons, extrinsic application of the recombinant $h C b \ln 1$ ( $r h C b \ln 1)$ protein to the $\mathrm{GC}$ axons stimulated their growth (Figure 6F), supporting a similar model as in the developing spinal cord that Cbln1 
bioRxiv preprint doi: https://doi org/10.1101/2021.11.16.468844; this version posted November 16,2021 . The copyright holder for this preprint (which was not certified by peer review) is the author/funder, who has granted bioRxiv a license to display the preprint in perpetuity. It is made available under aCC-BY 4.0 International license.

secreted from cerebellar GC axons works back to stimulate GC axon growth in the developing cerebellum. Detection of Nrxn1, 2, and 3 expression in GCs at IGL (Figure 6-figure supplement 1A,B) implied that neurexins would mediate the autocrine function of Cbln1 to stimulate GC axon growth in the developing cerebellum as in the spinal cord.

We continued to carefully examine the Cbln1 cKO cerebella. Immunostaining of the Purkinje cell (PC) marker Calbindin and the granule cell (GC) marker NeuN showed no difference between Cbln1 cKO and control cerebella at P8 (Figure 6G), suggesting that the neurogenesis of PC and GC in the cerebellum is not impaired. To investigate whether the in vitro regulation of GC axon growth by Cbln1 was recapitulated in vivo, we examined parallel fiber (PF) development in Cbln1 cKO mice by Dil labeling. Compared with control mice, the Dil-labeled parallel fiber lengths in Cbln1 cKO mouse pups at P6 were significantly decreased (Figure $6 H, I)$, indicating that the parallel fiber growth was impaired in Cbln1 cKO cerebella.

All these data suggested that cell-autonomous $\mathrm{Cbln} 1$ from granule cells is required for parallel fiber growth in the developing cerebellum, just as cell-autonomous Cbln1 from commissural axons stimulates $\mathrm{CA}$ axon growth in the developing spinal cord.

\section{Non-cell-autonomous Cbln1 regulates axon guidance of retinal ganglion cells in the optic chiasm}

The regulation of commissural axon guidance during midline crossing by the non-cell-autonomous Cbln1 from floor plate of the developing spinal cord inspired us to further test whether Cbln1 regulates axon guidance in other brain midline models. The optic chiasm (OC) is where retinal ganglion cell (RGC) axons from each eye cross the midline. The ipsi- and contra-lateral axon organization of RGC axons in OC is critical for binocular vision (Mason and Slavi 2020). We wanted to check whether Cbln1 contributed to axon guidance signaling in OC. RGCs do not express Cb/n1 (Figure 7A). However, both Cbln1 mRNA and Cbln1 protein were detected in the ventral diencephalon at the floor of the third ventricle which is adjacent to OC (Figure $7 B, C$ ), implying that Cbln1 has the right location to exert effects on OC. In vitro co-culture of retinal explants with COS7 
cell aggregates expressing Cbln1 showed that Cbln1 is sufficient to attract RGC axon turning (Figure $7 D)$

We next continued to explore whether Cbln1 physiologically regulates RGC axon guidance in OC at the ventral diencephalic midline. We generated Cbln1 cKO embryos using Nes-cre. As show in Figure 7E, Cbln1 expression in the ventral diencephalon was ablated. RGCs can be divided to ipsilateral and contralateral subgroups according to their projection laterality to the same or opposite side of the brain, respectively. The experiments checking expression of Cbln1 receptors in retina by in situ hybridization revealed that only Nrxn1 and Nrxn2 mRNA were detected in the developing retina (Figure 7F) while Nrxn3, GluD1 or GluD2 mRNA was not detected (Figure 7-figure supplement $1 A, B)$. Nrxn2 was further found to be only expressed in the contralateral RGCs marked by Brn3a (Figure 7G), suggesting that Cbln1 would only work on the contralateral RGCs. Consistent with this, Dil tracing of RGC axons showed that contralateral axon attraction to OC was impaired in the Cbln1 cKO mouse embryos compared with control embryos (Figure $7 H, I)$. We further checked the targeting of optic nerves to the brain by anterograde labeling with cholera toxin subunit B (CTB) and found that the ratio of ipsilateral area to contralateral area of the retinogeniculate projections was increased in CbIn1 cKO pups compared with control pups (Figure $7 J, K)$. These data suggest that the non-cell-autonomous Cbln1 regulates contralateral RGC axon guidance in the optic chiasm.

\section{Discussion}

Based on the in vitro and in vivo studies in mice, we have demonstrated that cell-autonomous and non-cell-autonomous Cbln1 regulates axon growth and guidance in multiple neural regions, respectively, suggesting a general role for Cbln1 in early nervous system development. Studies on Cbln1 so far have focused on its role as the synaptic organizer in cerebellum (Hirai et al. 2005; Matsuda et al. 2010; Uemura et al. 2010; Ito-Ishida et al. 2012; Yuzaki 2018; Ibata et al. 2019; Suzuki et al. 2020; Takeo et al. 2020) and cortex (Fossati et al. 2019). Whether Cbln1 works in earlier neuronal developmental processes prior to synapse formation or in other neural regions is not 
bioRxiv preprint doi: https://doi org/10.1101/2021.11.16.468844; this version posted November 16,2021 . The copyright holder for this preprint (which was not certified by peer review) is the author/funder, who has granted bioRxiv a license to display the preprint in perpetuity. It is made available under aCC-BY 4.0 International license.

303

known. Here we report that Cbln1 is expressed in developing spinal cord, cerebellum, and ventral diencephalon. We also found that Cbln1 regulates axon growth and guidance in multiple neural regions. These findings suggest that $\mathrm{Cb} \ln 1$ has dynamic spatial-temporal expression and function in the nervous system. Thus, in order to distinguish the early (axon development) and late (synapse formation) roles of Cbln1, it would be critical to more precisely control the timepoint of knocking out Cbln1. For example, inducible Cbln1 cKO would be necessary to explore its roles in synapse formation, in order to avoid disrupting its role in axon pathfinding.

During neural developmental stages before synapse formation, extracellular cues are required to direct axon growth and guidance (Stoeckli 2018). Most of these cues are non-cell-autonomous and secreted by sources such as the surrounding and target (intermediate or final) tissues. Here we found that non-cell-autonomous Cbln1 expressed and secreted from floor plate in the developing spinal cord and from ventral diencephalon in the developing brain works in a paracrine manner to regulate commissural axon and retinal ganglion axon guidance when they cross the midline.

In addition, we also found that cell-autonomous Cbln1 which is generated and secreted from commissural and cerebellar granule cell axons works in an autocrine manner to stimulate their own axon growth. Actually, other examples that axon-derived and remotely secreted cues regulate axon development have also been reported. The axonally secreted protein axonin-1 promotes neurite outgrowth of dorsal root ganglia (DRG) (Stoeckli et al. 1991). Wnt3a is expressed in RGCs and has the autocrine RGC axon growth-promoting activity (Harada et al. 2019). The $C$ terminus of the ER stressinduced transcription factor CREB3L2 was found to be secreted by DRG axons to promote DRG axon growth (McCurdy et al. 2019). Recent study suggests that axonally synthesized Wnt5a is secreted and promote cerebellar granule axon growth in an autocrine manner (Yu et al. 2021).

Thus, Cbln1 shows up as an example of molecules with dual roles as both non-cell-autonomous and cell-autonomous cues to regulate axon guidance and growth, respectively.

We found that neurexins, esp. Nrxn2, mediate Cbln1 functions in axon development. Neurexins are transmembrane proteins with a large extracellular region and a small intracellular C-terminal 
region (Reissner et al. 2013). Nrxns are alternatively spliced at six sites (named as SS1 to SS6)(Sudhof

2017), whereas Cbln1 only bind to SS4+ neurexins (Uemura et al. 2010). Extracellularly, $\alpha$-Nrxns bind

to Cbln1 via the LNS6 domain (laminin/neurexin/sex-hormone-binding globulin domain 6) which is

Südhof 2000; Biederer and Sudhof 2001; Mukherjee et al. 2008). It will be interesting to explore

\section{Key resources table}

\begin{tabular}{lll}
\hline Reagent type (species)or resource & Source or reference & Identifiers \\
\hline Antibodies & & \\
\hline Goat polyclonal anti-Alcam & R\&D Systems & Cat\# AF656, RRID: AB_355509 \\
Rabbit polyclonal anti-CbIn1 & Abcam & Cat\# ab64184, RRID: AB_1140961 \\
Rabbit polyclonal anti-CbIn1 & Frontier Institute & Cat\# Cbln1-Rb-Af270, RRID: \\
& & AB_2571672 \\
Rabbit polyclonal anti-Cbln1 & Abclonal & N/A (customized) \\
Chicken polyclonal anti-GFP & Abcam & Cat\# ab13970, RRID: AB_300798 \\
Goat polyclonal anti-Lhx9 & Santa Cruz Biotechnology & Cat\# sc-19350, RRID: AB_2249920 \\
Rabbit monoclonal anti-Lhx2 & Abcam & Cat\# ab184337 \\
Mouse monoclonal anti-Isl1/2 & DSHB & Cat\# 39.4D5, RRID, AB_2314683 \\
Rabbit polyclonal anti-Nrxn2 & Abcam & Cat\# ab34245, RRID: AB_776702 \\
Rabbit monoclonal anti-NeuN & Cell Signaling Technology & Cat\# 24307, RRID: AB_2651140 \\
Rabbit monoclonal anti- & Cell Signaling Technology & Cat\# 2837, RRID: AB_823575 \\
Neurofilament-L & & \\
Goat polyclonal anti-Robo3 & R\&D Systems & Cat\# AF3076, RRID: AB_2181865 \\
Goat polyclonal anti-Tag1 & R\&D Systems & Cat\# AF1714, RRID, AB_2245173 \\
Mouse monoclonal anti-Brn3a & Millipore & Cat\# MAB1585, RRID: AB_94166 \\
Mouse monoclonal anti-Calbindin & Swant & Cat\# 300, RRID: AB_10000347 \\
Mouse monoclonal anti-Tuj1 & Abcam & Cat\# ab78078, RRID: AB_2256751 \\
Mouse monoclonal anti- $\beta$-actin & Abcam & Cat\# ab6276, RRID: AB_2223210 \\
Mouse monoclonal anti-FLAG & Beyotime & Cat\# AF519 \\
Alexa 555 donkey anti-goat IgG & Thermo & Cat\# A-21432, RRID: AB_2535853 \\
Alexa 555 donkey anti-rabbit IgG & Thermo & Cat\# A-31572, RRID: AB_162543 \\
Alexa 488 donkey anti-mouse IgG & Thermo & Cat\# A-21202, RRID: AB_141607 \\
Alexa 488 donkey anti-rabbit IgG & Thermo & Cat\# A-21206, RRID: AB_2535792 \\
Alexa 488 donkey anti-goat IgG & Thermo & Cat\# A-11055, RRID: AB_2534102
\end{tabular}


Alexa 488 donkey anti-chicken IgY HRP donkey anti-mouse IgG HRP donkey anti-rabbit IgG HRP VHH anti-mouse IgG HRP VHH anti-rabbit IgG
Jackson ImmunoResearch

Abcam

Abcam

AlpaLife

AlpaLife
Cat\# 703-545-155, RRID: AB_2340375

Cat\# ab97030, RRID: AB_10680919

Cat\# ab16284, RRID: AB_955387

Cat\# KTSM1321

Cat\# KTSM1322

\begin{tabular}{|c|c|c|}
\hline \multicolumn{3}{|l|}{$\begin{array}{l}\text { Chemicals, Peptides, and } \\
\text { Recombinant Proteins }\end{array}$} \\
\hline Tamoxifen & Cayman & Cat\# 13258 \\
\hline $\begin{array}{l}\text { Lipofectamine } 3000 \text { Transfection } \\
\text { Reagent }\end{array}$ & Thermo & Cat\# L3000-001 \\
\hline $\begin{array}{l}\text { Recombinant Human Cerebellin-1 } \\
\text { Protein }\end{array}$ & R\&D Systems & Cat\# 6934-CB-025 \\
\hline $\begin{array}{l}\text { ChamQ }{ }^{\mathrm{TM}} \text { Universal SYBR qPCR } \\
\text { Master Mix }\end{array}$ & Vazyme & Cat\# Q711-02 \\
\hline DIG RNA labeling Kit (SP6/T7) & Roche & Cat\# 11175025910 \\
\hline tRNA & Roche & Cat\# 10109495001 \\
\hline Anti-Digoxigenin-AP & Roche & Cat\# 11093274910 \\
\hline NBT/BCIP & Roche & Cat\# 11681451001 \\
\hline DMEM, high glucose & Hyclone & Cat\# SH30243.01 \\
\hline Dulbecco's Modified Eagle's & Sigma & Cat\# D2429 \\
\hline \multicolumn{3}{|l|}{ Medium, $10 \times$, low glucose } \\
\hline Fetal Bovine Serum (FBS) & Gibco & Cat\# 10099-141 \\
\hline $\begin{array}{l}\text { Dulbecco's Phosphate-Buffered } \\
\text { Saline, } 1 \times \text { without calcium and } \\
\text { magnesium (DPBS) }\end{array}$ & Corning & Cat\# 21-031-CV \\
\hline Laminin I (mouse), Culrex & Trevigen & Cat\# 3400-010-01 \\
\hline Insulin & Sigma & Cat\# 16634 \\
\hline B27 serum-free supplement, $50 \times$ & Gibco & Cat\# 17504044 \\
\hline DMEM/F-12, GlutaMAX'⿳一 & Gibco & Cat\# 10565-018 \\
\hline Neurobasal Medium & Gibco & Cat\# 21103-049 \\
\hline Neurobasal-A Medium & Gibco & Cat\# 10888-022 \\
\hline Basal Medium Eagle & Gibco & Cat\# 21010046 \\
\hline Penicillin-Streptomycin & Gibco & Cat\# 15140-122 \\
\hline N-2 Supplement, $100 \times$ & Gibco & Cat\# 17502-048 \\
\hline Poly-D-Lysine & Trevigen & Cat\# 3439-100-01 \\
\hline Glucose & Sigma & Cat\# G8644 \\
\hline HBSS & Gibco & Cat\# 14175095 \\
\hline Trypsin & Sigma & Cat\# 59427C \\
\hline DNase I & sigma & Cat\# DN25 \\
\hline Puromycin & Sigma & Cat\# P8833 \\
\hline Paraformaldehyde & Sigma & Cat\# V900894 \\
\hline $\begin{array}{l}\text { O.C.T. Compound and Cryomolds, } \\
\text { Tissue-Tek }\end{array}$ & SAKURA & Cat\# 4583 \\
\hline Triton $x-100$ & Sigma & Cat\# V900502 \\
\hline $\begin{array}{l}\text { Mounting Medium, antifading } \\
\text { (with DAPI) }\end{array}$ & Beyotime & Cat\# P0131 \\
\hline Normal Sheep Serum & Millipore & Cat\# S22-100ML \\
\hline
\end{tabular}


HEK293T

COS-7

Experimental Models:

Organisms/Strains

Mouse: $\mathrm{Cb} \ln 1^{\mathrm{fl} / \mathrm{fl}}$

Mouse: Wnt1-cre

Mouse: Rosa26mTmG

Mouse: Nes-cre

Mouse: Foxa2-cre ${ }^{\mathrm{ERT}}$

Mouse: $\mathrm{Gli}^{+/-}$
ATCC

ATCC
Cat\# CRL-11268, RRID: CVCL_1926

Cat\# CRL-1651, RRID: CVCL_0224

\section{Oligonucleotides}

Cloning primers for chick Cbln1:

Fwd: ATGCGGGGCCCG

Rev: TTAAAGCGGGAACACC

Cloning primers for mouse Cbln1: This paper N/A

Fwd: CCGGAGGCGCGATGCT

Rev: ATTCCCGATACGTGCCAG

shRNA targeting sequence of

This paper

N/A

negative control pLKO.1-Puro

This paper

N/A

Jackson Laboratory

Cat\# JAX_003829

Jackson Laboratory

Cat\# JAX_007676

Jackson Laboratory

Cat\# JAX_003771

Jackson Laboratory

Cat\# JAX_008464

Jackson Laboratory

Cat\# JAX_008464

system:

GCATCAAGGTGAACTTCAAGA

shRNA targeting sequence of

negative control for pLKO.1-GFP

(Zhuang et al. 2019) N/A

system:

GCATCAAGGTGAACTTCAAGA

shRNA targeting sequence of

mouse $C b / n 1$ :

GGCTGGAAGTACTCAACCTTC

shRNA targeting sequence of

mouse Nrxn2:

This paper

N/A

N/A

CGTTCGTTTATTTCCCTCGAT

\begin{tabular}{|c|c|c|}
\hline $\begin{array}{l}\text { shRNA targeting sequence of } \\
\text { mouse } N r \times n 2 \alpha \text { : } \\
\text { GGACTTCTGCTGTTCAACTCA }\end{array}$ & This paper & N/A \\
\hline $\begin{array}{l}\text { shRNA targeting sequence of } \\
\text { mouse } N r \times n 2 \beta \text { : } \\
\text { CTCCCCCATCACCCGGATTTG }\end{array}$ & This paper & N/A \\
\hline $\begin{array}{l}\text { qPCR primers of mouse Cbln1 } \\
\text { Fwd: CCGAGATGAGTAATCGCACCA } \\
\text { Rev: } \\
\text { TCAACATGAGGCTCACCTGGATG }\end{array}$ & This paper & N/A \\
\hline $\begin{array}{l}\text { qPCR primers of mouse Nrxn2 } \\
\text { Fwd: TACCCGGCAGGAAACTTTGA } \\
\text { Rev: CCCCCTATCTTGATGGCAGC }\end{array}$ & This paper & N/A \\
\hline $\begin{array}{l}\text { qPCR primers of mouse } N r \times n 2 \alpha \text { : } \\
\text { Fwd: CTCAAGTCTGGGGCTGTCTG } \\
\text { Rev: ATAGCGTGTCCAATCCCTGC }\end{array}$ & This paper & N/A \\
\hline $\begin{array}{l}\text { qPCR primers of mouse } N r \times n 2 \beta \text { : } \\
\text { Fwd: GATGGATCCAGGCTTCACGG } \\
\text { Rev: GAAGGAAAACCAGAGCCCGA }\end{array}$ & This paper & N/A \\
\hline
\end{tabular}




\begin{tabular}{|c|c|c|}
\hline $\begin{array}{l}\text { qPCR primers of mouse Gapdh: } \\
\text { Fwd: } \\
\text { TTGTCAGCAATGCATCCTGCACCACC } \\
\text { Rev: } \\
\text { CTGAGTGGCAGTGATGGCATGGAC }\end{array}$ & (Mains et al. 2011) & $\mathrm{N} / \mathrm{A}$ \\
\hline $\begin{array}{l}\text { Probe primers of chick Cbln1: } \\
\text { Fwd: GAGAAGACGCCGCTCAGGTGT } \\
\text { Rev: CGGGTTGATTTGCGGTCCTTC }\end{array}$ & This paper & $\mathrm{N} / \mathrm{A}$ \\
\hline $\begin{array}{l}\text { Probe primers of mouse Cbln1: } \\
\text { Fwd: CCAAGACGTGACACGCGAG } \\
\text { Rev: CAGTAAGTGGCAGGGTTCAG }\end{array}$ & This paper & $\mathrm{N} / \mathrm{A}$ \\
\hline $\begin{array}{l}\text { Probe primers of mouse } N r \times n 1: \\
\text { Fwd: CAGGGAATGCGATCAGGAGG } \\
\text { Rev: AGACTTCTTCTCTGGCACGC }\end{array}$ & This paper & $\mathrm{N} / \mathrm{A}$ \\
\hline $\begin{array}{l}\text { Probe primers of mouse Nrxn2: } \\
\text { Fwd: TCACAGCCCTGGGTTGATTT } \\
\text { Rev: AGCAGCGACACACACAAAAG }\end{array}$ & This paper & $\mathrm{N} / \mathrm{A}$ \\
\hline $\begin{array}{l}\text { Probe primers of mouse Nrxn3: } \\
\text { Fwd: GTGAGATGGGGTGTACCACG } \\
\text { Rev: ACACACACACTGGTCAGAACC }\end{array}$ & This paper & $\mathrm{N} / \mathrm{A}$ \\
\hline $\begin{array}{l}\text { Probe primers of mouse GluD1: } \\
\text { Fwd: CATTGGCCTCCTTCTTGCCT } \\
\text { Rev: GAGGTGCCATGAGAGGTGTC }\end{array}$ & This paper & $\mathrm{N} / \mathrm{A}$ \\
\hline $\begin{array}{l}\text { Probe primers of mouse GluD2: } \\
\text { Fwd: GCCCCTACCGTGATGTCTTT } \\
\text { Rev: GTCAATGTCCAGAGGGGTCA }\end{array}$ & This paper & $\mathrm{N} / \mathrm{A}$ \\
\hline $\begin{array}{l}\text { Probe primers of mouse } N r \times n 2 \alpha \text { : } \\
\text { Fwd: GCAGGGATTGGACACGCTAT } \\
\text { Rev: GAACTGTGACTGCCTACCCC }\end{array}$ & This paper & $\mathrm{N} / \mathrm{A}$ \\
\hline $\begin{array}{l}\text { Probe template for } N r \times n 2 \beta \text { : } \\
\text { TGAGGGGGGACCCCTAGCCGCCCGC } \\
\text { GATGGATCCAGGCTTCACGGACCTT } \\
\text { GGCCTTCCCGCTGCGCGTACCCCGG } \\
\text { ATTCCCCGGCGGGATCCAGTTGATTT } \\
\text { GCTTGGCTCCGGACTGAGGCTCGGG } \\
\text { CTCTGGTTTTCCTTCGCTTCACCCCTA } \\
\text { CCCCCCTCTCGGAGCTCGCAACCGG } \\
\text { AGGGGGGCTTT }\end{array}$ & This paper & $\mathrm{N} / \mathrm{A}$ \\
\hline $\begin{array}{l}\text { Mouse genotyping primers for } \\
\text { mouse Cbln1 loxp site } 1 \text { : } \\
\text { Fwd: } \\
\text { ACGCGGGGACATTTGTTCTGGAGT } \\
\text { Rev: } \\
\text { ACGATGGGCTCTGTCTCATTCTGC }\end{array}$ & This paper & $\mathrm{N} / \mathrm{A}$ \\
\hline $\begin{array}{l}\text { Mouse genotyping primers for } \\
\text { mouse Cbln1 loxp site 2: } \\
\text { Fwd: AGAAAGGCGACCGAGCATAC } \\
\text { Rev: AGTGTGCAGAGCTAAGCGAA }\end{array}$ & This paper & $\mathrm{N} / \mathrm{A}$ \\
\hline Software and Algorithms & & \\
\hline GraphPad Prism 7.0 & GraphPad & ht \\
\hline
\end{tabular}




\begin{tabular}{ll}
\hline & SCR_002798 \\
ImageJ & https://imagej.nih.gov/ij/, \\
& RRID:SCR_002285 \\
\hline
\end{tabular}

\section{Animals}

342 Generation of $C b / n 1$ conditional knockout (cKO) mice was performed following procedures described 343 previously (Zhuang et al. 2019), with the whole coding sequence as the targeted region (Figure 2344 figure supplement $1 A$ ). Cbln $1^{f l /+}$ mice and corresponding Cre mice lines were used to generate Cbln1 345 cKO and littermate control embryos. Genotyping primers are as following: the first Cbln1-loxP site, 5'ACGCGGGGACATTTGTTCTGGAGT-3' and 5'-ACGATGGGCTCTGTCTCATTCTGC-3'; the second Cbln1IoxP site, 5'-AGAAAGGCGACCGAGCATAC-3' and 5'-AGTGTGCAGAGCTAAGCGAA-3'. Wnt1-cre

(Danielian et al. 1998), Rosa26mTmG (Muzumdar et al. 2007), Gli2 ${ }^{+-}$(Bai and Joyner 2001), Foxa2$\mathrm{cre}^{E R T}$ (Park et al. 2008), and Nes-cre (Tronche et al. 1999) mice used in this study were described in the indicated references and their stock numbers in The Jackson Laboratory are 003829, 007676, 007922,008464 , and 003771 respectively. All mice were housed in a specific pathogen-free animal experiments using mice were carried out following animal protocols approved by the Laboratory Animal Welfare and Ethics Committee of Southern University of Science and Technology. For timed pregnancy, embryos were identified as E0.5 when a copulatory plug was observed at noon. To induce Cre activity for Foxa2-cre ${ }^{E R T}$-derived Cbln1 cKO in floor plate, $8 \mathrm{mg}$ tamoxifen (Cayman Chemical) was given orally to E8.5 pregnant mice with an animal gauge feeding needle. Fertilized chick eggs were purchased from a local supplier and chick embryos developed in an incubator (BSS 420, Grumbach) were staged using the Hamburger and Hamilton staging system. For all experiments with mice or chick, a minimum of three (up to 20) embryos or pups was analyzed for each genotype or experimental condition. 
The chick spinal DCN-specific knockdown vector pMath1-eGFP-miRNA was a gift from Esther T.

365

366

367

368

369

370

371

372

373

Stoeckli (Wilson and Stoeckli 2013). DCN-specific overexpression vector pMath1-eGFP-IRES-MCS was constructed by replacing the miRNA cassette with an IRES sequence plus multiple coning sites (MCS). The coding sequence of chick Cbln1 was cloned from St. 23/24 chick spinal cord cDNA with primers 5'-ATGCGGGGCCCG-3' and 5'-TTAAAGCGGGAACACC-3'. In ovo electroporation was carried out using the $\mathrm{ECM}^{\circledR} 830$ Square Wave Electroporator (BTX) as previously described (Ji et al. 2009). Electroporation was performed at St.17 and embryos were collected and analyzed at St.23.

\section{Tissue and neuron culture}

All tissue culture reagents were from Thermo unless otherwise specified. DCN explant and neuronal culture were carried out as describe previously (Zhuang et al. 2019). The working concentration for recombinant human Cbln1 (R\&D Systems) was $500 \mathrm{ng} / \mathrm{ml}$. GPN (Abcam) was dissolved in DMSO and used at the working concentration of $50 \mu \mathrm{M}$. P6-P8 mouse cerebella were cut into small pieces with scissors after the meninges were carefully removed. The tissue was then digested in $5 \mathrm{ml} \mathrm{HBSS}$ containing $0.1 \%$ Trypsin and $0.04 \%$ DNase I in a $37^{\circ} \mathrm{C}$ water bath for 15 min before termination addition of $5 \mathrm{ml} \mathrm{BME}$ with 10\% FBS. Cell suspension was obtained by filtering with sterile cell strainers $(40 \mu \mathrm{m})$. After centrifuged at $200 \times \mathrm{g}$ for $5 \mathrm{~min}$, the cell pellets were resuspended in BME supplemented with $5 \%$ FBS, $1 \times$ GlutaMAX-1, $0.5 \%$ glucose and $1 \times$ penicillin/streptomycin. The neurons were then plated in PDL-coated cell culture plate and the medium was replaced by maintenance medium supplemented with $1 \times$ B27, $1 \times$ GlutaMAX-1, $0.5 \%$ glucose and $1 \times$ penicillin/streptomycin after $4 \mathrm{~h}$.

\section{Knockdown or overexpression using lentiviral system, RT-qPCR, and Western blotting}

The lentiviral knockdown constructs were made using pLKO.1-Puro or pLKO.1-GFP plasmids (Addgene) (Zhuang et al. 2019). The target sequences of shRNA are as following: shCbln1, 5'-




GGACTTCTGCTGTTCAACTCA-3'; shNrxn2 $\beta$, 5'-CTCCCCCATCACCCGGATTTG-3'; shCtrl for pLKO.1-Puro

system: 5'-GCATCAAGGTGAACTTCAAGA-3'; shCtrl for pLKO.1-GFP system: 5'-

GCATAAACCCGCCACTCATCT-3'. RT-qPCR was performed as previously reported(Zhuang et al. 2019).

Primers used in qPCR are as following: $m C b \ln 1,5^{\prime}$-CCGAGATGAGTAATCGCACCA-3' and 5'-

TCAACATGAGGCTCACCTGGATG-3'; mNrxn2, 5'-TACCCGGCAGGAAACTTTGA-3' and 5'-

CCCCCTATCTTGATGGCAGC-3'; $m N r \times n 2 \alpha, 5^{\prime}$-CTCAAGTCTGGGGCTGTCTG-3' and 5'-

GAAGGAAAACCAGAGCCCGA-3'; mGapdh: 5'-TTGTCAGCAATGCATCCTGCACCACC-3' and 5'-

The coding sequence of mouse Cbln1 was cloned from E11.5 mouse spinal cord cDNA with

Beyotime), $\beta$-actin (1:10000, Abcam). 
In situ hybridization using DIG-labeled RNA probes was carried out on sections from mouse or chick

417 tissue sections following a previously reported protocol (Ji and Jaffrey 2012). The primers used for

PCR in cloning the templates for generating RNA probes are as following (all mouse clones except indicated): Cbln1, 5'-CCAAGACGTGACACGCGAGG-3' and 5'-CAGTAAGTGGCAGGGTTCAG-3'; chick Cbln1, 5'-GAGAAGACGCCGCTCAGGTGT-3' and 5'-CGGGTTGATTTGCGGTCCTTC-3'; Nrxn1, 5' -

CAGGGAATGCGATCAGGAGG-3' and 5'-AGACTTCTTCTCTGGCACGC-3'; Nrxn2, 5'-

TCACAGCCCTGGGTTGATTT-3' and 5'-AGCAGCGACACACACAAAAG-3'; Nrxn3, 5'-

GTGAGATGGGGTGTACCACG-3' and 5'-ACACACACACTGGTCAGAACC-3'; GluD1, 5'-

CATTGGCCTCCTTCTTGCCT-3' and 5'-GAGGTGCCATGAGAGGTGTC-3'; GluD2, 5'-

GCCCCTACCGTGATGTCTTT-3' and 5'-GTCAATGTCCAGAGGGGTCA-3'; Nrxn2 $\alpha, 5^{\prime}$ -

GCAGGGATTGGACACGCTAT-3' and 5'-GAACTGTGACTGCCTACCCC-3'. The template for Nrxn2 $\beta$ -

specific RNA probe was synthesized (5'-TGAGGGGGGACCCCTAGCCGCCCGCGATGGATCCAGGCTTCA

\section{Axon guidance assay using co-culture of COS7 cell aggregates with DCN or retinal explants}

Aggregates of COS7 cells stably expressing Cbln1 were prepared by resuspending cells in rat tail

437 collagen gel and then placed into 24-well glass bottom plates (Nest). DCN explants were dissected

438 from E11 mouse embryos, immersed in collagen gel and placed 200-400 $\mu \mathrm{m}$ away from the COS7

439 aggregates. Explants and cell aggregates were co-cultured for $40-48 \mathrm{~h}$ in neurobasal medium 
442 B27, N21 MAX Media Supplement, GlutaMAX-1 and penicillin/streptomycin.

\section{Dil tracing of axons}

\section{CTB labelling of optic nerve}

To label RGC axon terminals in P4 mouse brain, RGC axons were anterogradely labeled by CTB experiment with the TissueFAXS 7.0 software.

\section{Immunostaining and immunofluorescence}

Immunostaining of tissue sections and immunofluorescence (IF) of cultured DCN explants and

culture medium as following: Neurobasal medium mixed with DMEM/F12 (1:1), supplemented with

Dil tracing of commissural axons in the spinal cord was performed as previously reported (Zhuang et al. 2019). Dil labeling of cerebellar parallel fibers was performed as previously described (Yamasaki et al. 2001). Dil tracing of optic nerves was performed as previously reported (Peng et al. 2018). (Cholera Toxin Subunit B) conjugated with Alexa Fluor ${ }^{\mathrm{TM}} 555$ (Invitrogen, C34776) through intravitreal injection $48 \mathrm{hr}$ before sacrifice. After PFA perfusion, the brains were fixed with 4\% PFA in $0.1 \mathrm{M} \mathrm{PB}$ overnight, dehydrated with $15 \%$ sucrose and $30 \%$ sucrose in $0.1 \mathrm{M} \mathrm{PB}$ overnight at $4^{\circ} \mathrm{C}$ sequentially, embedded with O.C.T. for coronal section, and cryosectioned at $12 \mu \mathrm{m}$ with Leica CM1950 Cryostat. The images were captured on Tissue Genostics with identical settings for each group in the same neurons were done as previously described (Zhuang et al. 2019). The spinal cord open-books were prepared similarly as Dil tracing, and their immunostaining was performed with similar procedures as tissues sections except that all incubation and washing were done in 24-well plates and the openbooks were mounted onto slides and covered with cover slips before confocal imaging. For IF of axon surface Cbln1 in cultured DCN neurons after GPN treatment, the permeabilization step was omitted and there was no Triton x-100 in antibody incubation buffers. Immunostaining of tissue sections from the cerebellum and the optic chiasm were done as previously described (Hirai et al. 
2005; Peng et al. 2018). The dilutions and sources of antibodies used in immunostaining and immunofluorescence are as following: Cbln1 (1:1000, Abcam), Cbln1 (1:50, Frontier Institute), Lhx2 (1:500, Abcam), Alcam (1:200, R\&D Systems), Lhx9 (1:50, Santa Cruz Biotechnology), Robo3 (1:500, R\&D Systems), Tag1 (1:200, R\&D Systems), NFM (1:1000, Cell Signaling Technology), GFP (1:1000, Abcam), Isl1/2 (1:500, DSHB), Nrxn2 (1:200, Abcam), Calbindin (1:200, Swant), NeuN (1:500, Cell Signaling Technology), Brn3a (1:200, Millipore). Alexa Fluor-conjugated secondary antibodies (Thermo) were used at 1:1000 (555) or 1:500 (488). Fluorescent images were acquired using laserscanning confocal microscopes Nikon A1R with NIS software, Leica SP8 with LASX software, or Zeiss LSM 800 with Zen software. All images were collected with identical settings for each group in the same experiment. Quantification of immunofluorescence signals was performed using ImageJ.

\section{Statistical analysis}

Statistical analysis was performed with GraphPad Prism 7.0. Most of our data are represented as the box and whisker plots unless otherwise specified in the figure legends, and the settings are: $25-75$ percentiles (boxes), minimum and maximum (whiskers), and medians (horizontal lines). Unpaired Student's $\mathrm{t}$ test was performed for comparison between two groups and ANOVA with Tukey's multiple comparison test was performed to the comparison of three or more groups. ${ }^{*}$ indicates statistically significant: ${ }^{*} p<0.05,{ }^{* *} p<0.01,{ }^{* * *} p<0.001, * * * * p<0.0001$

\section{Acknowledgements}

We thank Esther T. Stoeckli for the pMath1-eGFP-miRNA vector, members of Ji and Jaffrey laboratories for help, technical support, and comments on the manuscript. This work was supported by National Natural Science Foundation of China (31871038 and 32170955 to S.-J.J.), Shenzhen-Hong Kong Institute of Brain Science-Shenzhen Fundamental Research Institutions (2021SHIBS0002, 2019SHIBS0002), High-Level University Construction Fund for Department of Biology (internal grant 
no. G02226301), Science and Technology Innovation Commission of Shenzhen Municipal

Government (ZDSYS20200811144002008), and NIH (R35NS111631 to S.R.J.).

\section{Author contributions}

S.-J.J. and S.R.J. conceived the project and designed experiments; S.-J.J. performed screening and identification of DEGs in DCNs; P.H. and Y.S. performed and analyzed most of the experiments with help of Z.Y., M.Z. and Q.W.; X.L., C.Y., and J.Z. performed experiments using chick embryos; S.-J.J., S.R.J., and P.H. wrote the manuscript with editing and input from other authors.

\section{Ethics}

All experiments using mice were carried out following the animal protocols approved by the Laboratory Animal Welfare and Ethics Committee of Southern University of Science and Technology (approval numbers: SUSTC-JY2017004, SUSTech-JY202102081).

\section{Competing interests}

The authors have declared that no competing interests exist.

\section{Data availability statement}

The microarray data has been deposited to the Gene Expression Omnibus (GEO) with accession number GSE169448.

\section{References}

Augsburger A, Schuchardt A, Hoskins S, Dodd J, Butler S. 1999. BMPs as mediators of roof plate repulsion of commissural neurons. Neuron 24:127-141. PMID: 10677032

Bai CB, Joyner AL. 2001. Gli1 can rescue the in vivo function of Gli2. Development 128:5161-5172. PMID: 11748151

Biederer T, Sudhof TC. 2001. CASK and protein 4.1 support F-actin nucleation on neurexins. J Biol Chem 276:47869-47876. DOI: https://doi.org/10.1074/jbc.M105287200, PMID: 11604393 
Biederer T, Südhof TC. 2000. Mints as adaptors. Direct binding to neurexins and recruitment of munc18. J Biol Chem 275:39803-39806. DOI: https://doi.org/10.1074/jbc.C000656200, PMID: 11036064

Brose K, Bland KS, Wang KH, Arnott D, Henzel W, Goodman CS, Tessier-Lavigne M, Kidd T. 1999. Slit proteins bind Robo receptors and have an evolutionarily conserved role in repulsive axon guidance. Cell 96:795-806. PMID: 10102268

Butler SJ, Dodd J. 2003. A role for BMP heterodimers in roof plate-mediated repulsion of commissural axons. Neuron 38:389-401. PMID: 12741987

Cerrato V, Mercurio S, Leto K, Fucà E, Hoxha E, Bottes S, Pagin M, Milanese M, Ngan CY, Concina $G$, Ottolenghi S, Wei CL, Bonanno G, Pavesi G, Tempia F, Buffo A, Nicolis SK. 2018. Sox2 conditional mutation in mouse causes ataxic symptoms, cerebellar vermis hypoplasia, and postnatal defects of Bergmann glia. Glia 66:1929-1946. DOI: https://doi.org/10.1002/glia.23448, PMID: 29732603

Charron F, Stein E, Jeong J, McMahon AP, Tessier-Lavigne M. 2003. The morphogen sonic hedgehog is an axonal chemoattractant that collaborates with netrin-1 in midline axon guidance. Cell 113:11-23. PMID: 12679031

Chen Z, Gore BB, Long H, Ma L, Tessier-Lavigne M. 2008. Alternative splicing of the Robo3 axon guidance receptor governs the midline switch from attraction to repulsion. Neuron 58:325-332. DOI: https://doi.org/10.1016/i.neuron.2008.02.016, PMID: 18466743

Colak D, Ji SJ, Porse BT, Jaffrey SR. 2013. Regulation of axon guidance by compartmentalized nonsense-mediated mRNA decay. Cell 153:1252-1265. DOI: https://doi.org/10.1016/i.cell.2013.04.056, PMID: 23746841

Danielian PS, Muccino D, Rowitch DH, Michael SK, McMahon AP. 1998. Modification of gene activity in mouse embryos in utero by a tamoxifen-inducible form of Cre recombinase. Curr Biol 8:13231326. PMID: 9843687

Fossati M, Assendorp N, Gemin O, Colasse S, Dingli F, Arras G, Loew D, Charrier C. 2019. TransSynaptic Signaling through the Glutamate Receptor Delta-1 Mediates Inhibitory Synapse Formation in Cortical Pyramidal Neurons. Neuron 104:1081-1094 e1087. DOI: https://doi.org/10.1016/j.neuron.2019.09.027, PMID: 31704028

Harada H, Farhani N, Wang XF, Sugita S, Charish J, Attisano L, Moran M, Cloutier JF, Reber M, Bremner R, Monnier PP. 2019. Extracellular phosphorylation drives the formation of neuronal circuitry. Nat Chem Biol 15:1035-1042. DOI: https://doi.org/10.1038/s41589-019-0345-z, PMID: $\underline{31451763}$

Hata Y, Butz S, Südhof TC. 1996. CASK: a novel dlg/PSD95 homolog with an N-terminal calmodulindependent protein kinase domain identified by interaction with neurexins. J Neurosci 16:24882494. DOI: https://doi.org/10.1523/jneurosci.16-08-02488.1996, PMID: 8786425

Hernandez-Enriquez B, Wu Z, Martinez E, Olsen O, Kaprielian Z, Maness PF, Yoshida Y, TessierLavigne M, Tran TS. 2015. Floor plate-derived neuropilin-2 functions as a secreted semaphorin sink to facilitate commissural axon midline crossing. Genes Dev 29:2617-2632. DOI: https://doi.org/10.1101/gad.268086.115, PMID: 26680304

Hirai H, Pang Z, Bao D, Miyazaki T, Li L, Miura E, Parris J, Rong Y, Watanabe M, Yuzaki M, Morgan JI. 2005. Cbln1 is essential for synaptic integrity and plasticity in the cerebellum. Nat Neurosci 8:1534-1541. DOI: https://doi.org/10.1038/nn1576, PMID: 16234806

Ibata K, Kono M, Narumi S, Motohashi J, Kakegawa W, Kohda K, Yuzaki M. 2019. Activity-Dependent Secretion of Synaptic Organizer Cbln1 from Lysosomes in Granule Cell Axons. Neuron 102:11841198.e1110. DOI: https://doi.org/10.1016/j.neuron.2019.03.044, PMID: 31072786

Islam SM, Shinmyo Y, Okafuji T, Su Y, Naser IB, Ahmed G, Zhang S, Chen S, Ohta K, Kiyonari H, Abe T, Tanaka S, Nishinakamura R, Terashima T, Kitamura T, Tanaka H. 2009. Draxin, a repulsive guidance protein for spinal cord and forebrain commissures. Science 323:388-393. DOI: https://doi.org/10.1126/science.1165187, PMID: 19150847

Ito-Ishida A, Miyazaki T, Miura E, Matsuda K, Watanabe M, Yuzaki M, Okabe S. 2012. Presynaptically released Cbln1 induces dynamic axonal structural changes by interacting with GluD2 during 
cerebellar synapse formation. Neuron 76:549-564. DOI:

https://doi.org/10.1016/i.neuron.2012.07.027, PMID: 23141067

Ji SJ, Jaffrey SR. 2012. Intra-axonal translation of SMAD1/5/8 mediates retrograde regulation of trigeminal ganglia subtype specification. Neuron 74:95-107. DOI: https://doi.org/10.1016/i.neuron.2012.02.022, PMID: 22500633

Ji SJ, Periz G, Sockanathan S. 2009. Nolz1 is induced by retinoid signals and controls motoneuron subtype identity through distinct repressor activities. Development 136:231-240. DOI: https://doi.org/10.1242/dev.028043, PMID: 19056829

Kidd T, Bland KS, Goodman CS. 1999. Slit is the midline repellent for the robo receptor in Drosophila. Cell 96:785-794. PMID: 10102267

Lyuksyutova Al, Lu CC, Milanesio N, King LA, Guo N, Wang Y, Nathans J, Tessier-Lavigne M, Zou Y. 2003. Anterior-posterior guidance of commissural axons by Wnt-frizzled signaling. Science 302:1984-1988. DOI: https://doi.org/10.1126/science.1089610, PMID: 14671310

Mains RE, Kiraly DD, Eipper-Mains JE, Ma XM, Eipper BA. 2011. Kalrn promoter usage and isoform expression respond to chronic cocaine exposure. BMC neuroscience 12:20. DOI: https://doi.org/10.1186/1471-2202-12-20, PMID: 21329509

Mason C, Slavi N. 2020. Retinal Ganglion Cell Axon Wiring Establishing the Binocular Circuit. Annu Rev Vis Sci. DOI: https://doi.org/10.1146/annurev-vision-091517-034306, PMID: 32396770

Matsuda K, Miura E, Miyazaki T, Kakegawa W, Emi K, Narumi S, Fukazawa Y, Ito-Ishida A, Kondo T, Shigemoto R, Watanabe M, Yuzaki M. 2010. Cbln1 is a ligand for an orphan glutamate receptor delta2, a bidirectional synapse organizer. Science 328:363-368. DOI: https://doi.org/10.1126/science.1185152, PMID: 20395510

McCormick LE, Gupton SL. 2020. Mechanistic advances in axon pathfinding. Curr Opin Cell Biol 63:1119. DOI: https://doi.org/10.1016/i.ceb.2019.12.003, PMID: 31927278

McCurdy EP, Chung KM, Benitez-Agosto CR, Hengst U. 2019. Promotion of Axon Growth by the Secreted End of a Transcription Factor. Cell Rep 29:363-377.e365. DOI: https://doi.org/10.1016/i.celrep.2019.08.101, PMID: 31597097

Moreno-Bravo JA, Roig Puiggros S, Mehlen P, Chedotal A. 2019. Synergistic Activity of Floor-Plateand Ventricular-Zone-Derived Netrin-1 in Spinal Cord Commissural Axon Guidance. Neuron 101:625-634.e623. DOI: https://doi.org/10.1016/j.neuron.2018.12.024, PMID: 30661739

Muguruma K, Nishiyama A, Ono Y, Miyawaki H, Mizuhara E, Hori S, Kakizuka A, Obata K, Yanagawa Y, Hirano T, Sasai Y. 2010. Ontogeny-recapitulating generation and tissue integration of ES cellderived Purkinje cells. Nat Neurosci 13:1171-1180. DOI: https://doi.org/10.1038/nn.2638, PMID: $\underline{20835252}$

Mukherjee K, Sharma M, Urlaub H, Bourenkov GP, Jahn R, Südhof TC, Wahl MC. 2008. CASK Functions as a Mg2+-independent neurexin kinase. Cell 133:328-339. DOI: https://doi.org/10.1016/i.cell.2008.02.036, PMID: 18423203

Muzumdar MD, Tasic B, Miyamichi K, Li L, Luo L. 2007. A global double-fluorescent Cre reporter mouse. Genesis 45:593-605. DOI: https://doi.org/10.1002/dvg.20335, PMID: 17868096

Nawabi H, Briancon-Marjollet A, Clark C, Sanyas I, Takamatsu H, Okuno T, Kumanogoh A, Bozon M, Takeshima K, Yoshida Y, Moret F, Abouzid K, Castellani V. 2010. A midline switch of receptor processing regulates commissural axon guidance in vertebrates. Genes Dev 24:396-410. DOI: https://doi.org/10.1101/gad.542510, PMID: 20159958

Okada A, Charron F, Morin S, Shin DS, Wong K, Fabre PJ, Tessier-Lavigne M, McConnell SK. 2006. Boc is a receptor for sonic hedgehog in the guidance of commissural axons. Nature 444:369-373. DOI: https://doi.org/10.1038/nature05246, PMID: 17086203

Padamsey Z, McGuinness L, Bardo SJ, Reinhart M, Tong R, Hedegaard A, Hart ML, Emptage NJ. 2017. Activity-Dependent Exocytosis of Lysosomes Regulates the Structural Plasticity of Dendritic Spines. Neuron 93:132-146. DOI: https://doi.org/10.1016/j.neuron.2016.11.013, PMID: 27989455

Paixao S, Balijepalli A, Serradj N, Niu J, Luo W, Martin JH, Klein R. 2013. EphrinB3/EphA4-mediated guidance of ascending and descending spinal tracts. Neuron 80:1407-1420. DOI: https://doi.org/10.1016/j.neuron.2013.10.006, PMID: 24360544 
Park EJ, Sun X, Nichol P, Saijoh Y, Martin JF, Moon AM. 2008. System for tamoxifen-inducible expression of cre-recombinase from the Foxa2 locus in mice. Dev Dyn 237:447-453. DOI: https://doi.org/10.1002/dvdy.21415, PMID: 18161057

Peng J, Fabre PJ, Dolique T, Swikert SM, Kermasson L, Shimogori T, Charron F. 2018. Sonic Hedgehog Is a Remotely Produced Cue that Controls Axon Guidance Trans-axonally at a Midline Choice Point. Neuron 97:326-340 e324. DOI: https://doi.org/10.1016/j.neuron.2017.12.028, PMID: 29346753

Reissner C, Runkel F, Missler M. 2013. Neurexins. Genome Biol 14:213. DOI: https://doi.org/10.1186/gb-2013-14-9-213, PMID: 24083347

Sabatier C, Plump AS, Le M, Brose K, Tamada A, Murakami F, Lee EY, Tessier-Lavigne M. 2004. The divergent Robo family protein rig-1/Robo3 is a negative regulator of slit responsiveness required for midline crossing by commissural axons. Cell 117:157-169. PMID: 15084255

Stoeckli ET. 2018. Understanding axon guidance: are we nearly there yet? Development 145 . DOI: https://doi.org/10.1242/dev.151415, PMID: 29759980

Stoeckli ET, Kuhn TB, Duc CO, Ruegg MA, Sonderegger P. 1991. The axonally secreted protein axonin1 is a potent substratum for neurite growth. The Journal of cell biology 112:449-455. DOI: https://doi.org/10.1083/jcb.112.3.449, PMID: 1991792

Sudhof TC. 2017. Synaptic Neurexin Complexes: A Molecular Code for the Logic of Neural Circuits. Cell 171:745-769. DOI: https://doi.org/10.1016/i.cell.2017.10.024, PMID: 29100073

Suzuki K, Elegheert J, Song I, Sasakura H, Senkov O, Matsuda K, Kakegawa W, Clayton AJ, Chang VT, Ferrer-Ferrer M, Miura E, Kaushik R, Ikeno M, Morioka Y, Takeuchi Y, Shimada T, Otsuka S, Stoyanov S, Watanabe M, Takeuchi K, Dityatev A, Aricescu AR, Yuzaki M. 2020. A synthetic synaptic organizer protein restores glutamatergic neuronal circuits. Science 369 . DOI: https://doi.org/10.1126/science.abb4853, PMID: 32855309

Takeo YH, Shuster SA, Jiang L, Hu MC, LuginbuhI DJ, Rülicke T, Contreras X, Hippenmeyer S, Wagner MJ, Ganguli S, Luo L. 2020. GluD2- and Cbln1-mediated competitive interactions shape the dendritic arbors of cerebellar Purkinje cells. Neuron. DOI: https://doi.org/10.1016/j.neuron.2020.11.028, PMID: 33352118

Tronche F, Kellendonk C, Kretz O, Gass P, Anlag K, Orban PC, Bock R, Klein R, Schutz G. 1999. Disruption of the glucocorticoid receptor gene in the nervous system results in reduced anxiety. Nat Genet 23:99-103. DOI: https://doi.org/10.1038/12703, PMID: 10471508

Uemura T, Lee SJ, Yasumura M, Takeuchi T, Yoshida T, Ra M, Taguchi R, Sakimura K, Mishina M. 2010. Trans-synaptic interaction of GluRdelta2 and Neurexin through Cbln1 mediates synapse formation in the cerebellum. Cell 141:1068-1079. DOI: https://doi.org/10.1016/i.cell.2010.04.035, PMID: 20537373

Wilson NH, Stoeckli ET. 2013. Sonic hedgehog regulates its own receptor on postcrossing commissural axons in a glypican1-dependent manner. Neuron 79:478-491. DOI: https://doi.org/10.1016/j.neuron.2013.05.025, PMID: 23931997

Wilson SI, Shafer B, Lee KJ, Dodd J. 2008. A molecular program for contralateral trajectory: Rig-1 control by LIM homeodomain transcription factors. Neuron 59:413-424. DOI: https://doi.org/10.1016/i.neuron.2008.07.020, PMID: 18701067

Wu Z, Makihara S, Yam PT, Teo S, Renier N, Balekoglu N, Moreno-Bravo JA, Olsen O, Chedotal A, Charron F, Tessier-Lavigne M. 2019. Long-Range Guidance of Spinal Commissural Axons by Netrin1 and Sonic Hedgehog from Midline Floor Plate Cells. Neuron 101:635-647.e634. DOI: https://doi.org/10.1016/j.neuron.2018.12.025, PMID: 30661738

Yamasaki T, Kawaji K, Ono K, Bito H, Hirano T, Osumi N, Kengaku M. 2001. Pax6 regulates granule cell polarization during parallel fiber formation in the developing cerebellum. Development 128:31333144. PMID: 11688562

Yasumura M, Yoshida T, Lee SJ, Uemura T, Joo JY, Mishina M. 2012. Glutamate receptor $\delta 1$ induces preferentially inhibitory presynaptic differentiation of cortical neurons by interacting with neurexins through cerebellin precursor protein subtypes. Journal of Neurochemistry 121:705-716. DOI: https://doi.org/10.1111/j.1471-4159.2011.07631.x, PMID: 22191730 
Yu J, She Y, Yang L, Zhuang M, Han P, Liu J, Lin X, Wang N, Chen M, Jiang C, Zhang Y, Yuan Y, Ji SJ. 2021. The m6A Readers YTHDF1 and YTHDF2 Synergistically Control Cerebellar Parallel Fiber Growth by Regulating Local Translation of the Key Wnt5a Signaling Components in Axons. Adv Sci. DOI: https://doi.org/10.1002/advs.202101329,

Yuzaki M. 2018. Two Classes of Secreted Synaptic Organizers in the Central Nervous System. Annu Rev Physiol 80:243-262. DOI: https://doi.org/10.1146/annurev-physiol-021317-121322, PMID: 29166241

Zhuang M, Li X, Zhu J, Zhang J, Niu F, Liang F, Chen M, Li D, Han P, Ji SJ. 2019. The m6A reader YTHDF1 regulates axon guidance through translational control of Robo3.1 expression. Nucleic acids research 47:4765-4777. DOI: https://doi.org/10.1093/nar/gkz157, PMID: 30843071

Zou Y, Stoeckli E, Chen H, Tessier-Lavigne M. 2000. Squeezing axons out of the gray matter: a role for slit and semaphorin proteins from midline and ventral spinal cord. Cell 102:363-375. PMID: $\underline{10975526}$ 
bioRxiv preprint doi: https://doi.org/10.1101/2021.11.16.46884. this version posted November 16,2021 . The copyright holder for this preprint (which was not certified by peer review) is the author/funder, who has granted bioRxiv a license to display the preprint in perpetuity. It is made available under aCC-BY 4.0 International license.
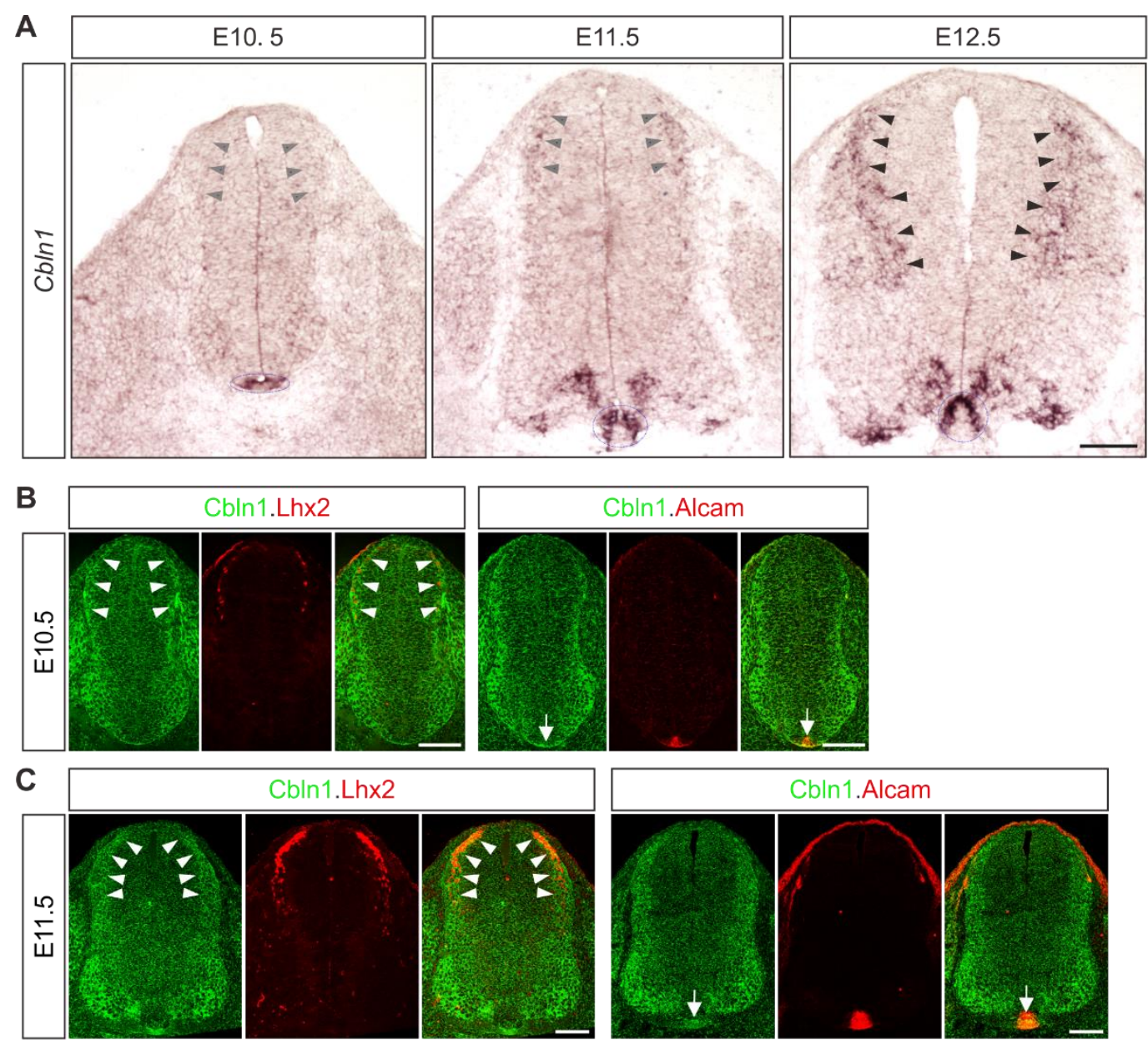

Cbln1.Lhx2
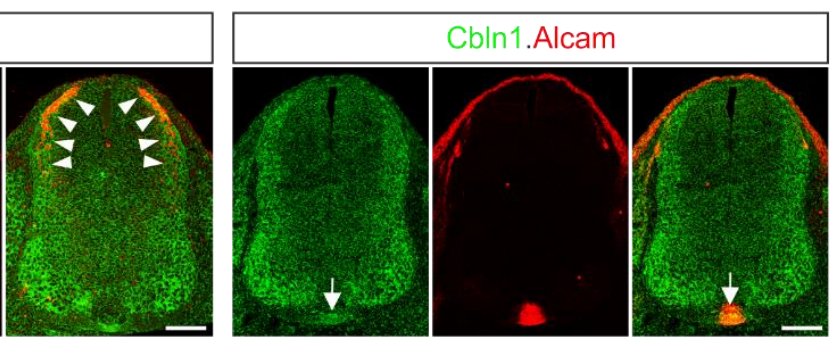

D
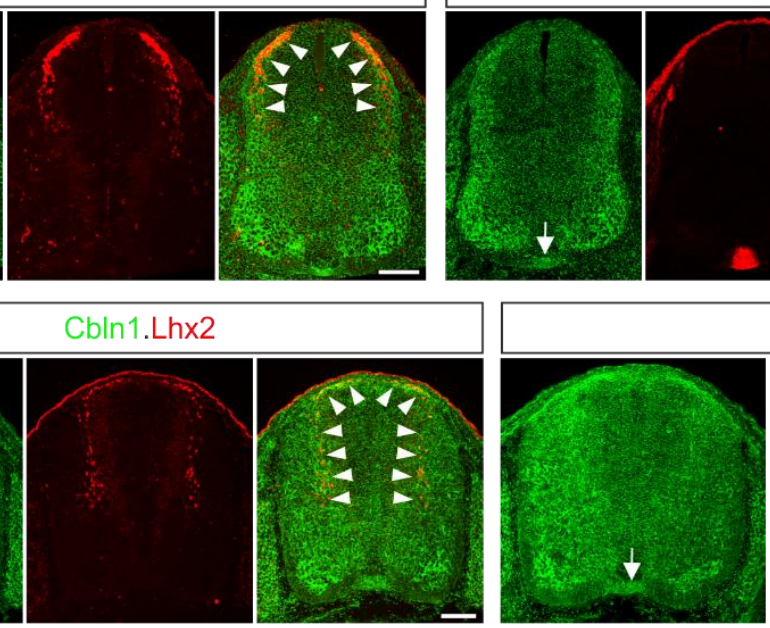

Cbln1.Alcam
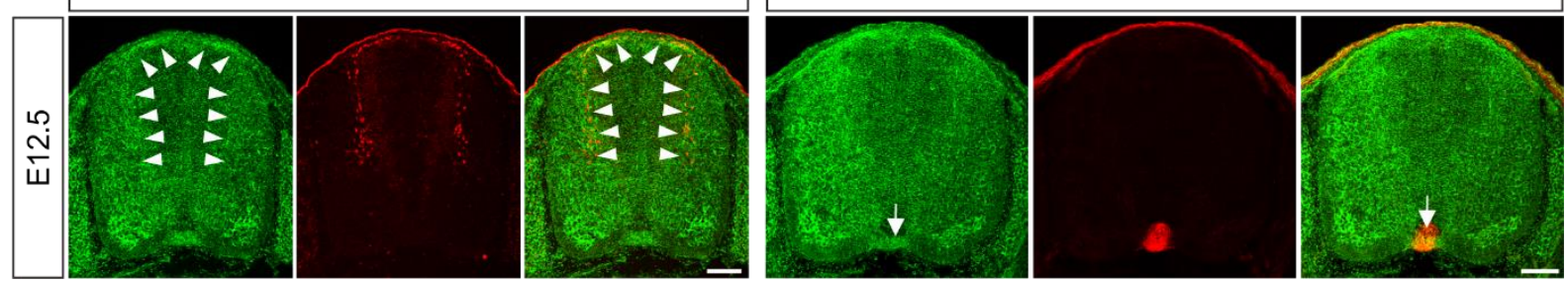

Figure 1. Expression patterns of $\mathrm{Cb} / n 1$ and $\mathrm{Cb} \ln 1$ in the developing mouse spinal cord.

694 (A) In situ hybridization was carried out using a DIG-labelled RNA probe against Cbln1 in spinal cord

695 cross-sections during E10.5 E12.5. Arrowheads and circled areas indicate the expression of Cbln1 in

696 the dorsal commissural neurons (DCN) and the floor plate, respectively. Scale bar, $100 \mu \mathrm{m}$.

(B-D) Co-immunostaining of Cbln1 with Lhx2 or Alcam in spinal cord cross-sections during 
bioRxiv preprint doi: https://doi.org/10.1101/2021.11.16.468844; this version posted November 16, 2021. The copyright holder for this preprint (which was not certified by peer review) is the author/funder, who has granted bioRxiv a license to display the preprint in perpetuity. It is made available under aCC-BY 4.0 International license.

701
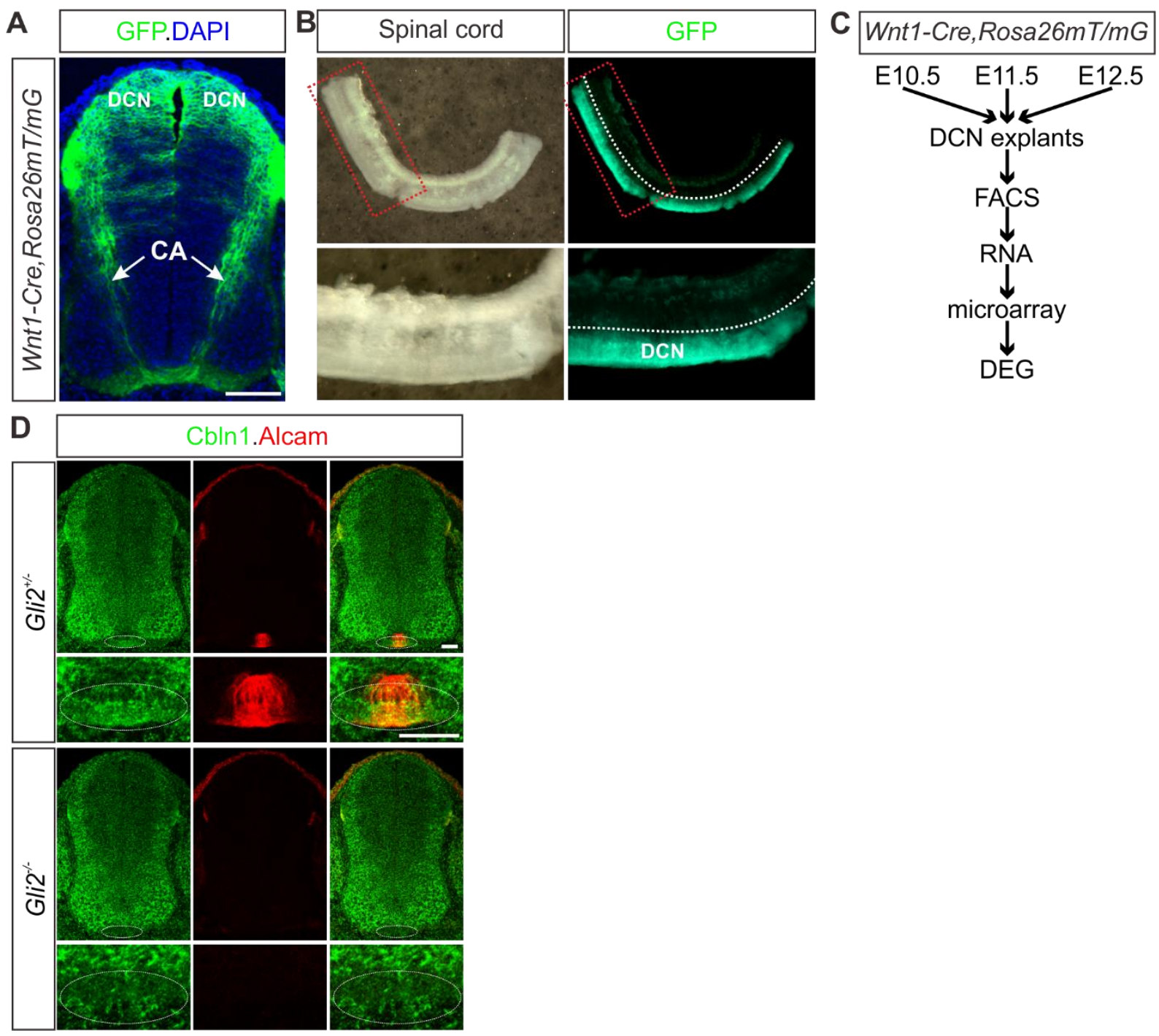

Figure 1-figure supplement 1. Screening of the differentially expressed genes in the mouse

embryonic dorsal spinal cord.

705 (A) The embryonic dorsal spinal neurons were genetically labeled with eGFP by crossing Wnt1-cre

with Rosa26mTmG mice. Immunofluorescence of cross-sections of E11.5 spinal cord was shown. DCN, dorsal commissural neurons. CA, commissural axons. Scale bar, $100 \mu \mathrm{m}$. 
bioRxiv preprint doi: https://doi.org/10.1101/2021.11.16.468844 this version posted November 16,2021 . The copyright holder for this preprint (which was not certified by peer review) is the author/funder, who has granted bioRxiv a license to display the preprint in perpetuity. It is made available under aCC-BY 4.0 International license.

(B) The dissected E11.5 spinal cords were shown in both bright-field and fluorescent images. The

regions in the red dotted boxes were shown with higher magnification in the lower images. The dotted white line indicates where to cut and separate dorsal and ventral spinal cord.

713 (D) Co-immunostaining of Cbln1 with Alcam in spinal cord cross-sections of Gli2 KO and its littermate

A
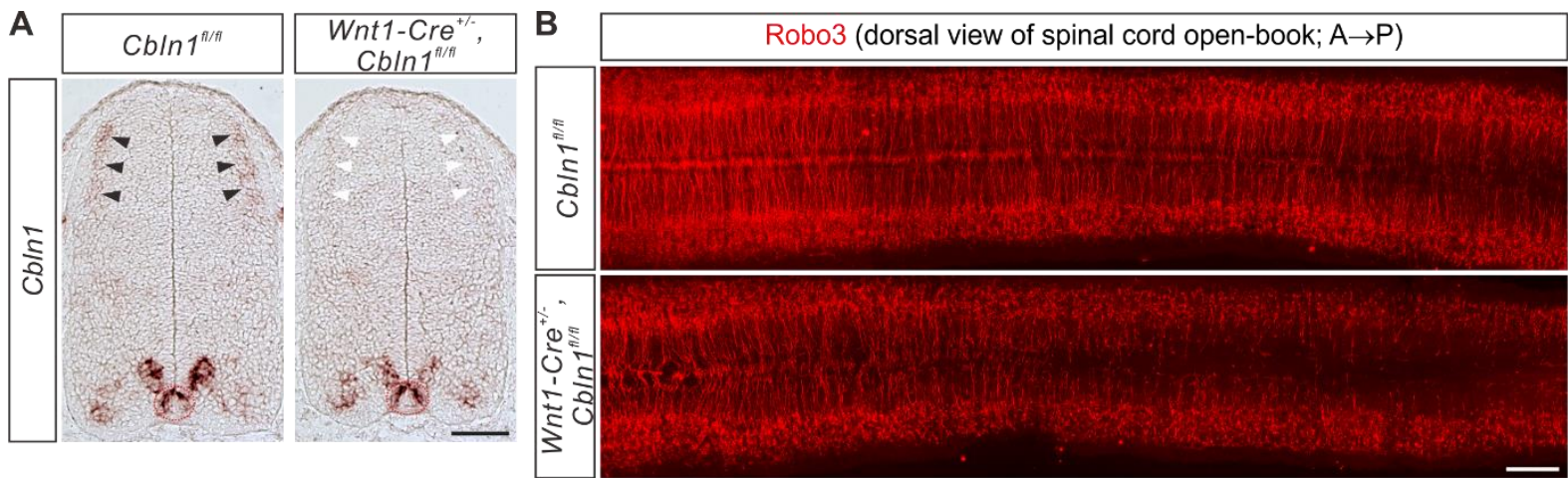

\section{E}

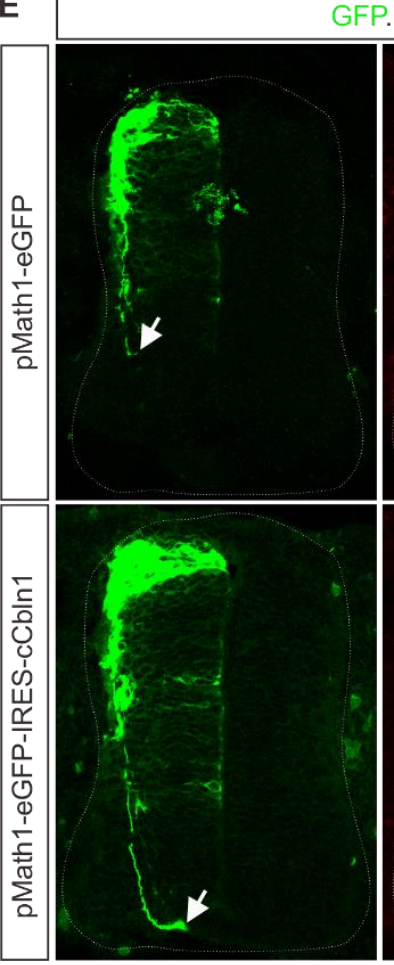

C

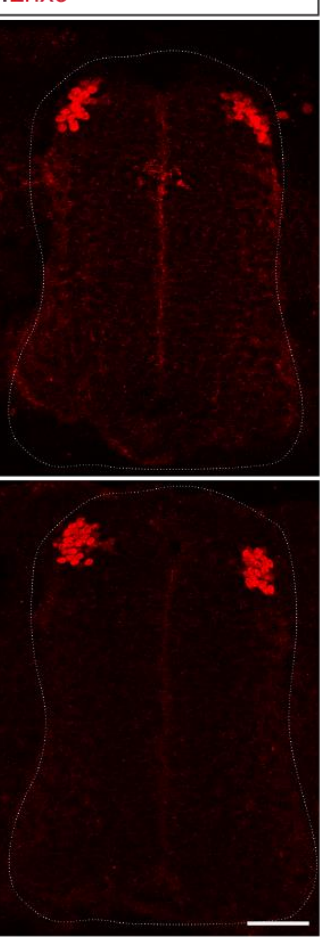




pMath1-eGFP

$\square$ pMath1-eGFP-IRES-cCbIn1 
Figure 2. Cell-autonomous CbIn1 is both required and sufficient to stimulate commissural axon growth in vivo.

(A) Specific depletion of Cbln1 in the dorsal spinal cord of Wnt1-Cre ${ }^{+/-}, C b / n 1^{f l / f l}$ cKO mouse embryos. In situ hybridization of E11.5 spinal cord sections using RNA probes against Cbln1 confirmed specific ablation of Cbln1 from the dorsal commissural neurons (DCNs). Black arrowheads indicate Cbln1 expression in control DCNs and white arrowheads highlight the missing Cbln1 expression in cKO DCNs. Expression of Cbln1 in floor plate (in red dotted circles) and other parts are not affected in DCNspecific Cbln1 cKO spinal cords. Scale bar, $100 \mu \mathrm{m}$.

(B) DCN-specific Cbln1 cKO caused dramatic commissural axon growth defects in vivo. Commissural axons were marked by Robo3 by immunostaining in spinal cord open-books at E10.5. The lengths of commissural axons are much shorter and the numbers of commissural axons are much fewer in Cbln1 cKO spinal cords compared with their littermate controls. Notice that these differences are more obvious in posterior ends of spinal cords. A, anterior; P, posterior. Scale bar, $200 \mu \mathrm{m}$.

(C, D) Quantification of commissural axon numbers and lengths in (B). The spinal cords were divided to bins $(500 \mu \mathrm{m})$ along the anterior-posterior $(A \rightarrow P)$ direction and the lengths and numbers of commissural axons in each bin were quantified. All data are mean $\pm \mathrm{SEM}: C b / n 1^{f l / f l}(n=9$ embryos) vs Wnt1-Cre ${ }^{+/-}, C b \ln 1^{f l / f l}\left(n=12\right.$ embryos); * $p=0.014$ for Bin 6 in $(C) ;{ }^{*} p=0.015$ for Bin 3 in (D); * $p=$ 0.049 for Bin 4 in (D); *p= 0.041 for Bin 5 in (D); by unpaired Student's $t$ test.

(E) Unilateral DCN-specific overexpression of $c C b / n 1$ by in ovo electroporation of pMath1-eGFP-IREScCbln1 enhanced commissural axon growth in chick neural tubes. Lhx9 marks dI1 DCNs and eGFP marks electroporated DCNs and their axons. The arrows point commissural axon terminals. Shown are the representative images from 10 chick embryos with pMath1-eGFP-IRES-cCbIn1 and 8 embryos with control plasmid.

$(\mathbf{F}, \mathbf{G})$ Quantification of commissural axon length and $\mathrm{Lh} \times 9^{+}$neuron numbers in (E). All data are represented as box and whisker plots: for (F), pMath1-eGFP-IRES-cCbln1 ( $n=35$ sections) vs pMath1- 
bioRxiv preprint doi: https://doi.org/10.1101/2021.11.16.468844; this version posted November 16, 2021. The copyright holder for this preprint (which was not certified by peer review) is the author/funder, who has granted bioRxiv a license to display the preprint in perpetuity. It is made available under aCC-BY 4.0 International license.

A

Wild-type allele

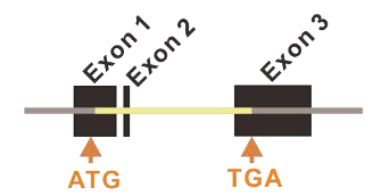

Targeted allele

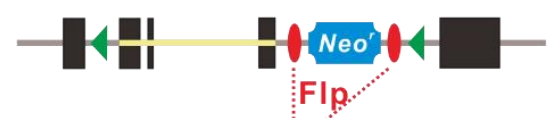

Floxed allele

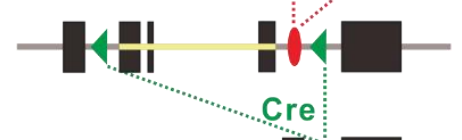

cKO after Cre recombination
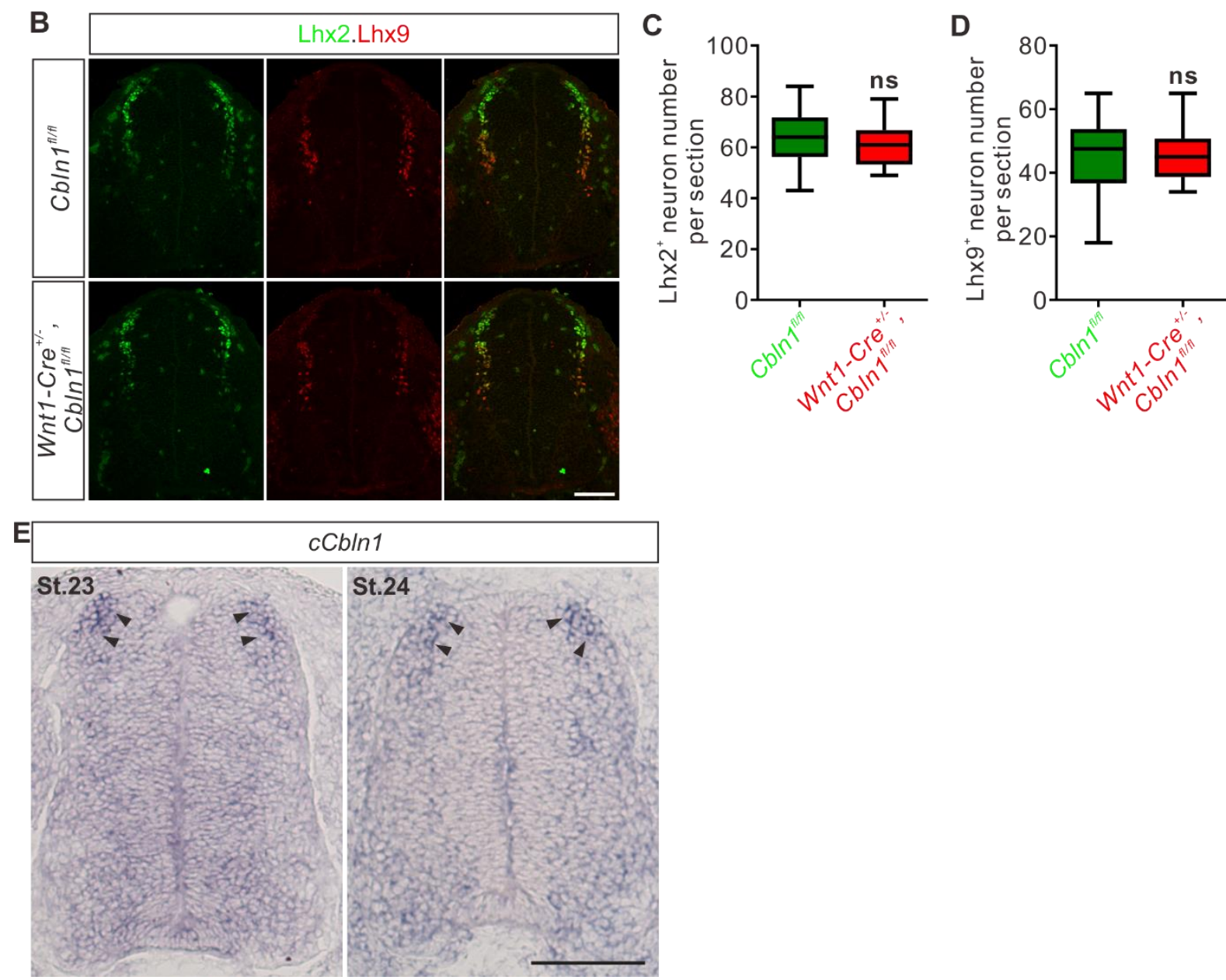

Figure 2-figure supplement 1. DCN-specific cKO of Cbln1 does not affect neurogenesis and

\section{patterning of spinal DCNs.}

(A) Schematic drawings showing the generation of $C b / n 1 \mathrm{cKO}$. The coding sequence of $C b / n 1$ is deleted after Cre-mediated recombination. 
bioRxiv preprint doi: https://doi.org/10.1101/2021.11.16.468844; this version posted November 16, 2021. The copyright holder for this preprint (which was not certified by peer review) is the author/funder, who has granted bioRxiv a license to display the preprint in perpetuity. It is made available under aCC-BY 4.0 International license.

(B) Lhx2 and Lhx9 immunostaining in E11.5 spinal cord indicated that CbIn1 cKO in DCNs does not disturb neurogenesis and patterning of spinal DCNs. Scale bar, $100 \mu \mathrm{m}$. sections) vs Wnt1-Cre ${ }^{+/-}, C b l n 1^{f l / f l}$ ( $n=16$ sections); ns, not significant; $p=0.46$ for Lhx $2^{+}$neurons in (C); $p=0.99$ for Lhx $9^{+}$neurons in (D); by unpaired Student's $t$ test.
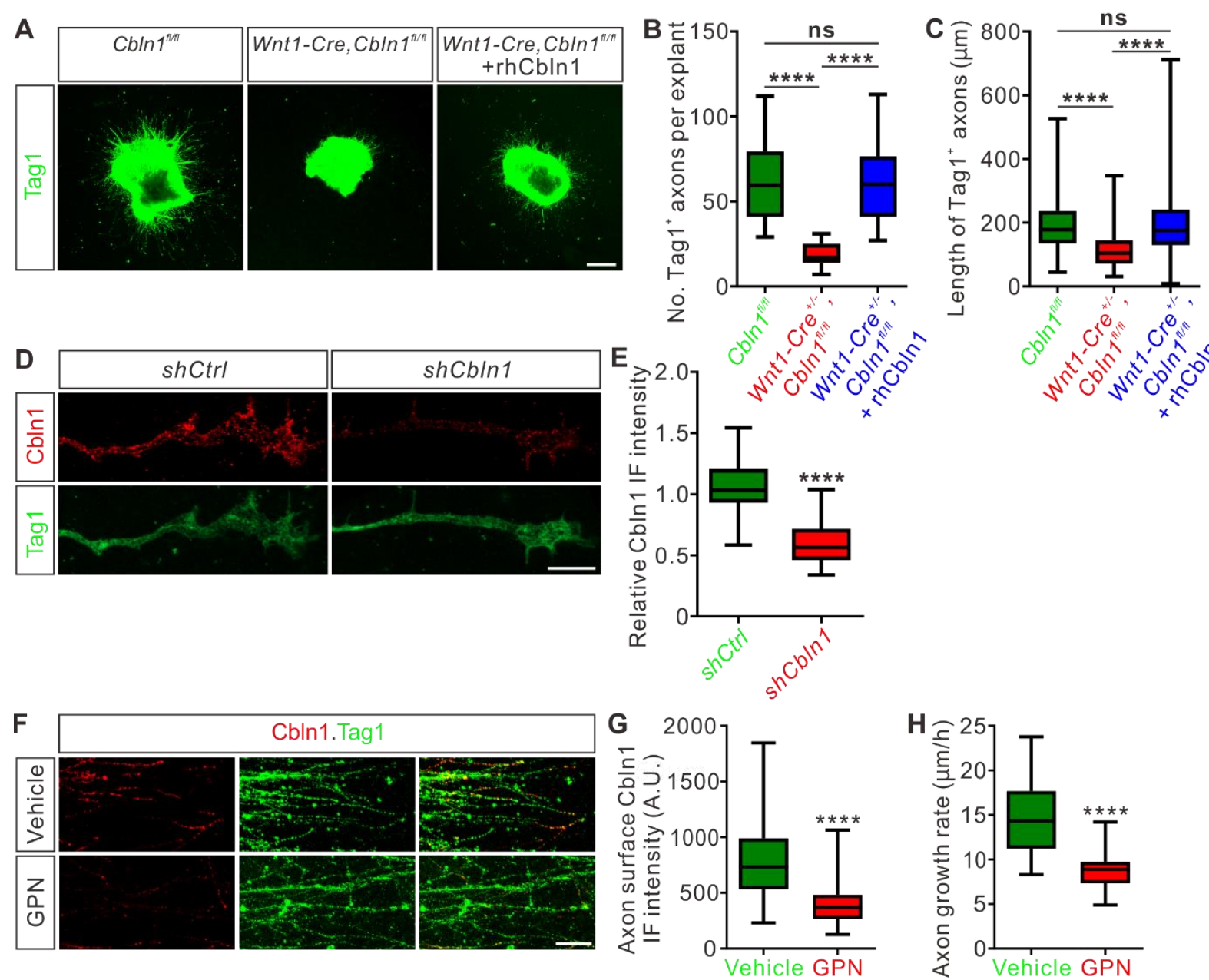

Figure 3. Cbln1 is secreted from commissural axon growth cones and stimulates commissural axon 
(A) Extrinsic Cbln1 could rescue commissural axon growth defects caused by cell-autonomous ablation of Cbln1 in the dorsal commissural neurons (DCN). DCN explants dissected from E10.5 mouse embryos were cultured in vitro and commissural axon length was monitored by immunostaining of Tag1, a commissural axon marker. Compared with $C b / n 1^{f / f l}$, DCN explants of Wnt1-Cre ${ }^{+/}, C b l n 1^{f l f f l}$ embryos showed significant commissural axon growth defects. These defects were rescued by adding the recombinant human Cbln1 protein (rhCbln1, $500 \mathrm{ng} / \mathrm{ml}$ ) to the cultures.

(B, C) Quantification of Tag $1^{+}$commissural axon numbers and lengths in (A). Data are represented as box and whisker plots. For (B), **** $p=1.69 \mathrm{E}-06, C b / n 1^{f / f f l}\left(n=14\right.$ explants) vs Wnt1-Cre ${ }^{+/-}, C b / n 1^{f / f f l}(n$ $=14$ explants) ${ }^{* * * *} p=6.23 \mathrm{E}-07$, Wnt1-Cre ${ }^{+/-}, C b \ln 1^{f / f f}$ vs Wnt1-Cre ${ }^{+/-}, C b \ln 1^{f / f f l}+\operatorname{rhCbln} 1(\mathrm{n}=16$ explants); ns, not significant $(p=0.99), C b \ln 1^{f / f f l}$ vs $W n t 1-C r e^{+-}, C b / n 1^{f \mid f l}+\operatorname{rhCbln} 1$. For $(C),{ }^{* * * *} p=$ 6.61E-11, $C b / n 1^{f \mid f l}\left(n=876\right.$ axons) vs Wnt1-Cre ${ }^{+/-}, C b / n 1^{f / f f l}\left(n=274\right.$ axons); ${ }^{* * * *} p=6.61 \mathrm{E}-11$, Wnt1$\mathrm{Cre}^{+/}, \mathrm{Cb} \ln 1^{f l / f l}$ vs Wnt1-Cre ${ }^{+/}, \mathrm{Cb} \ln 1^{f l / f l}+\operatorname{rhCb} \ln 1$ ( $n=1013$ axons); ns, not significant $(p=0.91)$, $C b / n 1^{f l f f l}$ vs Wnt1-Cre ${ }^{+/}, C b / n 1^{f \mid f l}+$ rhCbln1. By one-way analysis of variance (ANOVA) followed by Tukey's multiple comparison test. neurons from E11 mouse embryos were cultured in vitro and Cbln1 IF signals were imaged after lentiviral shRNA infection. Loss of Cbln1 IF signals after shCb/n1 infection indicated the specificity of Cbln1 IF signals in commissural axons and growth cones. Scale bar, $10 \mu \mathrm{m}$.

(E) Quantification of axonal Cbln1 IF signals in (D). Data are represented as box and whisker plots: $\operatorname{shCtrl}\left(n=55\right.$ axons) vs shCbln1 ( $n=68$ axons), ${ }^{* * *} p=5.65 \mathrm{E}-31$, by unpaired Student's $t$ test. (F) Cbln1 is exocytosed from commissural axons via lysosomes. Robust Cbln1 IF signals were detected on the commissural axon surface of cultured DCN explants and were eliminated after blocking exocytosis with GPN treatment for $10 \mathrm{~min}$. Scale bar, $50 \mu \mathrm{m}$. plots: Vehicle ( $n=140$ axons) vs GPN ( $n=126$ axons), ${ }^{* * *} p=1.94 \mathrm{E}-26$, by unpaired Student's $t$ test. 




Figure 3-figure supplement 1 . Knockdown of mCbln1 using lentiviral shRNA.

(A) Validation of knockdown of $C b \ln 1$ using lentiviral shCbln1. Since Cbln1 is abundant in cerebellar unpaired Student's $t$ test. 


803 (A) Co-culture of DCN explants from E11 mouse spinal cords with COS7 cell aggregates expressing also enhanced axon growth. Scale bar, $200 \mu \mathrm{m}$. for (B), $\operatorname{Ctrl}(n=1336$ axons) vs OE ( $n=1051$ axons), $* * * * p=1.93 \mathrm{E}-70$; for (C), $\operatorname{Ctrl}(n=16$ explants) vs OE ( $n=14$ explants), ${ }^{* * * *} p=1.97 \mathrm{E}-08$; by unpaired Student's $t$ test.

(D) Specific ablation of Cbln1 in the floor plate of Foxa2-Cre $e^{+/}, \mathrm{Cbln} 1^{f / f f} \mathrm{cKO}$ mouse embryos was confirmed by in situ hybridization of E11.5 spinal cord sections. Expression of Cbln1 in the floor plate

813 was completely lost in the cKO spinal cord (white asterisk) compared with the control embryos (black 814 asterisk). Black arrowheads indicate the unchanged Cb/n1 expression in DCNs of both genotypes. Scale bar, $100 \mu \mathrm{m}$.

(E) The axon guidance defects of pre-crossing commissural axons were observed by Tag1 immunostaining in floor plate-specific CbIn1 cKO and control embryos at E11.5. Higher magnification views of the floor plate region in the white dotted boxes are also shown (bottom). The pair of yellow arrowheads denotes the thickness of the ventral commissure (VC). The double-arrowed line measures the distance between the point of intersection (of the main pre-crossing commissural axon bundle with the ventral edge of spinal cord) and the midline (indicated by the dotted line). Scale bars,

$82250 \mu \mathrm{m}$.

$823(\mathbf{F}, \mathbf{G})$ Quantification of the VC thickness and the distance from the main bundle intersection point to 824 the midline. The VC thickness was normalized to the height (dorsal to ventral) of spinal cord. All data 825 are represented as box and whisker plots: $C b / n 1^{f l / f l}\left(n=62\right.$ sections) vs Foxa2-Cre ${ }^{+/-}, C b \ln 1^{f l / f l}(n=60$ sections), ${ }^{* * * *} p=1.69 \mathrm{E}-06$ for $(\mathbf{F}),{ }^{* * * *} p=1.07 \mathrm{E}-07$ for $(\mathbf{G})$, by unpaired Student's $t$ test. 
827 (H) Dil labeling of E11.5 spinal cord open-books traced commissural axon guidance behaviors during

828 midline crossing. The region between two white dotted lines indicates the floor plate. The white,

829 yellow and green arrowheads indicate the commissural axons with aberrant behaviors such as

830 ipsilateral turning, slower growing or winding crossing, respectively. Scale bar, $50 \mu \mathrm{m}$.

831 (I) Quantification of the percentages of commissural axons with different guidance behaviors. All

832 data are mean \pm SEM. and represented as histogram: $C_{b l n 1^{f / f f l}}\left(n=45\right.$ Dil injections) vs Foxa2-Cre ${ }^{+/-}$

$833, C b / n 1^{f l / f l}\left(n=32\right.$ Dil injections), ${ }^{* * * *} p=3.36 \mathrm{E}-17$ for normal crossing, ${ }^{* * * *} p=8.86 \mathrm{E}-10$ for ipsilateral

834 turning, ${ }^{* * * *} p=6.14 \mathrm{E}-07$ for slower growing, ${ }^{*} p=0.033$ for winding crossing, by unpaired Student's

$835 \quad t$ test. 

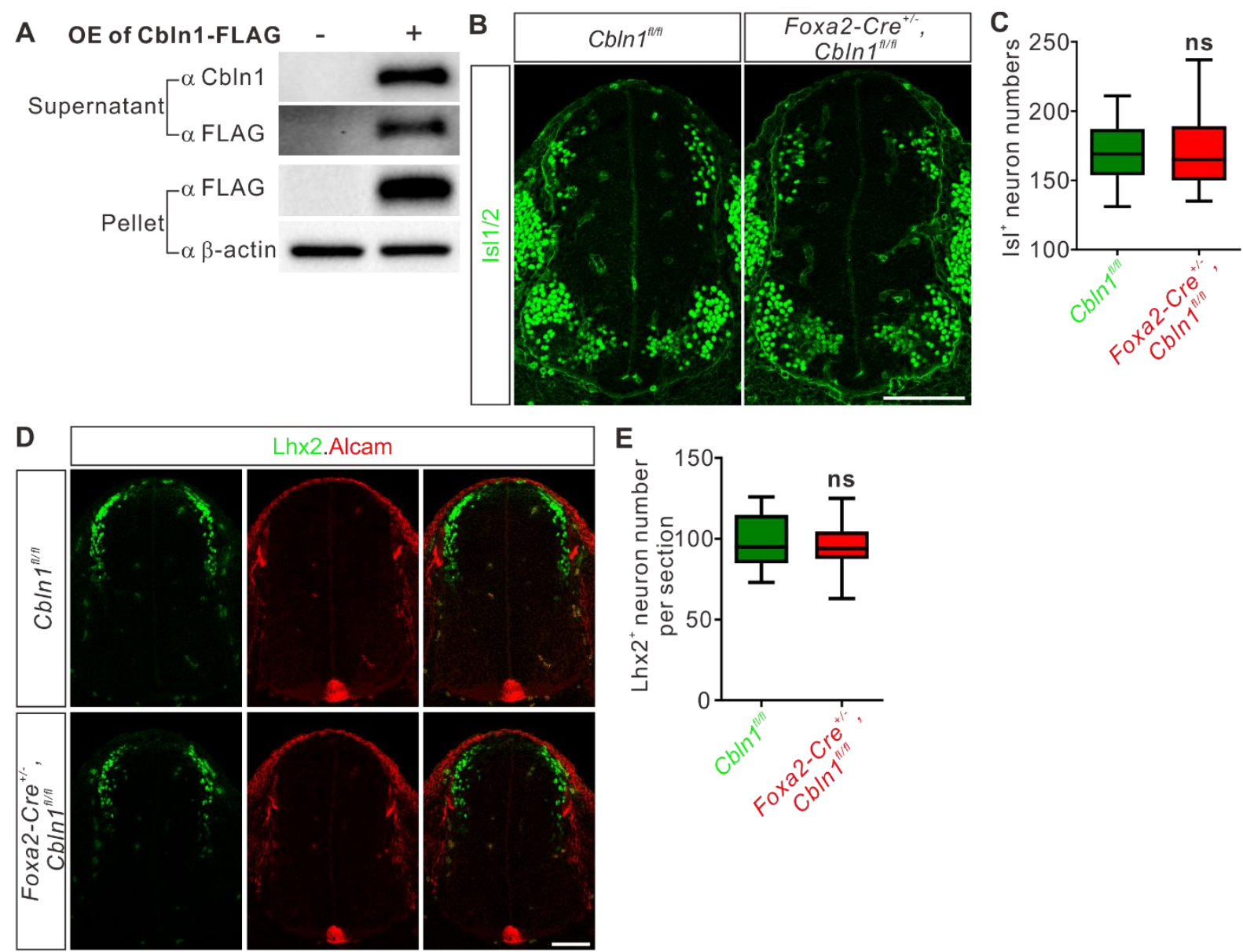

F

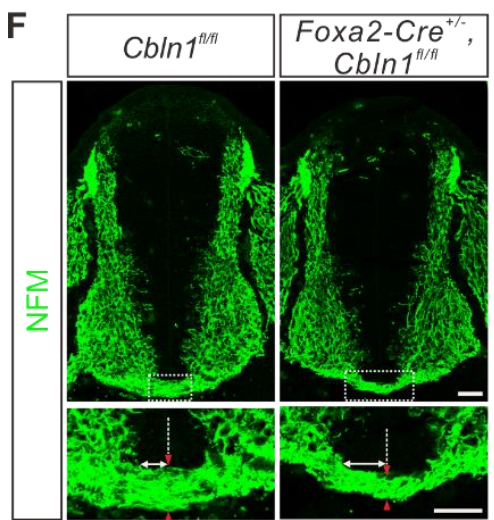



Figure 4-figure supplement 1. Floor plate-specific Cbln1 cKO does not disturb neural patterning or neurogenesis in the developing spinal cord.

(A) Overexpression and secretion of Cbln1 tagged by FLAG in COS7 cells were validated by WB.

(B, C) Isl1/2 immunostaining showed normal patterning of spinal cord in the floor plate-specific Cb/n1 cKO embryos (B). Isl1/2 marks different interneurons and motor neurons in spinal cord. Scale bar, $100 \mu \mathrm{m}$. The data for quantification of $|\mathrm{s}| 1 / 2^{+}$neuron numbers are represented as box and whisker 
plots (C): $C b / n 1^{f \mid f l}\left(n=42\right.$ sections) vs Foxa2-Cre ${ }^{+/}, C b / n 1^{f \mid f l}$ ( $n=49$ sections); ns, not significant ( $p=$

(D, E) The floor plate-specific cKO of Cbln1 does not disturb DCN neurogenesis, spinal cord patterning, or floor plate development. Lhx2 and Alcam immunostainings of E11.5 spinal cord were used to mark

$t$ test.

(F) The axon guidance defects of pre-crossing commissural axons were observed by NFM views of the FP region in the white dotted boxes are also shown (bottom). The pair of red arrowheads denotes the thickness of the ventral commissure (VC). The double-arrowed line measures the distance between the point of intersection (of the main pre-crossing commissural axon bundle with the ventral edge of spinal cord) and the midline (indicated by the dotted line). Scale bars,

$85850 \mu \mathrm{m}$.

$859(\mathbf{G}, \mathbf{H})$ Quantification of the VC thickness and the distance from the main bundle intersection point to the midline. All data are represented as box and whisker plots: $C b \ln 1^{f / f l}$ ( $n=49$ sections) vs Foxa2- 
bioRxiv preprint doi: https://doi.org/10.1101/2021.11.16 46884- this version posted November 16,2021 . The copyright holder for this preprint (which was not certified by peer review) is the author/funder, who has granted bioRxiv a license to display the preprint in perpetuity. It is made available under aCC-BY 4.0 International license.


G

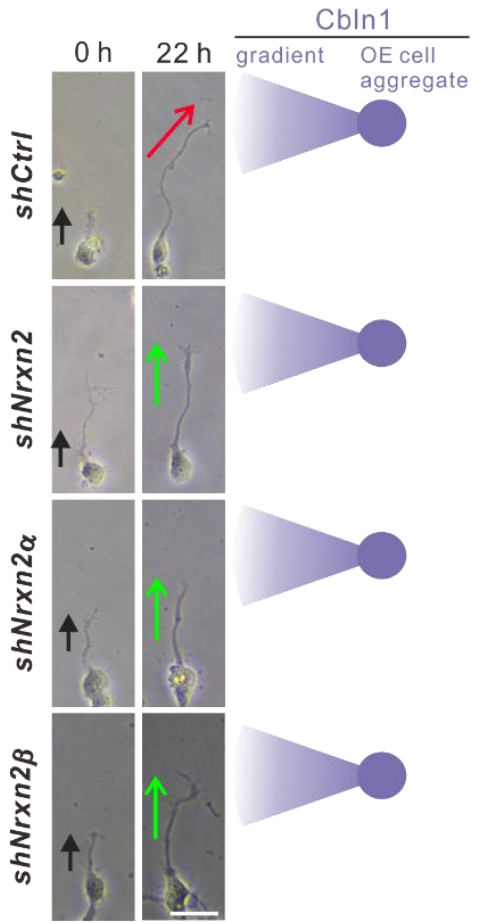

Rose plots
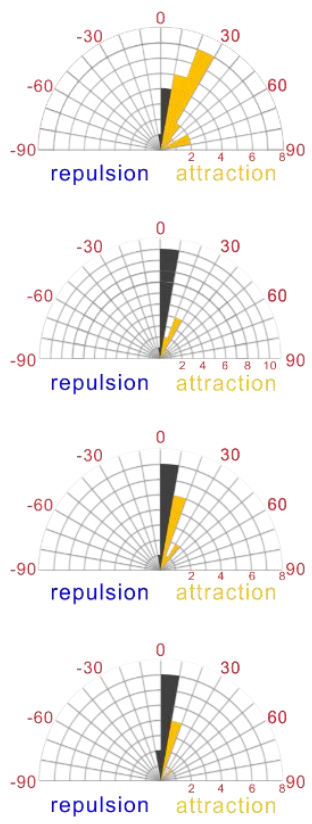

Figure 5. Nrxn2 mediates Cbln1-induced commissural axon growth and guidance as its receptor.

(A, B) Nrxn2, Nrxn2 $\alpha$ and Nrxn2 $\beta$ mRNAs were detected in E11.5 spinal cord cross-sections by in situ 
in B) or absence (Nrxn1 and Nrxn3 in A) of the corresponding mRNAs in DCNs, respectively. Scale bars, $100 \mu \mathrm{m}$.

870 (C) Robust Nrxn2 IF signals were detected in the commissural axons and growth cones. Dissociated DCN neurons from E11 mouse embryos were cultured in vitro and Nrxn2 IF signals were imaged after lentiviral shRNA infection. Loss of Nrxn2 IF signals after shNrxn2 infection indicated the specificity of Nrxn2 IF signals in the commissural axons and growth cones. Scale bar, $10 \mu \mathrm{m}$. shCtrl ( $n=69$ axons) vs shNrxn2 ( $n=65$ axons), ${ }^{* * * *} p=3.75 \mathrm{E}-39$, by unpaired Student's $t$ test. Tag1 IF. White arrowheads indicate the axon terminals. Scale bar, $100 \mu \mathrm{m}$. represented as box and whisker plots: $\operatorname{shCtrl}\left(n=63\right.$ axons) vs $\operatorname{shNrxn2}\left(n=53\right.$ axons), ${ }^{* * * *} p=1.41 \mathrm{E}-$ 15; shCtrl vs shNrxn2 $\alpha$ ( $n=48$ axons), ${ }^{* * * *} p=4.30 \mathrm{E}-18 ;$ shCtrl vs $\operatorname{shNrxn} 2 \beta\left(n=48\right.$ axons), ${ }^{* * * *} p=$ 6.27E-05; by one-way analysis of variance (ANOVA) followed by Tukey's multiple comparison test. (G) Knockdown of Nrxn2, Nrxn2 $\alpha$ or Nrxn2 $\beta$ in DCNs disturbed commissural axon turning toward Cbln1-expressing cell aggregates. Dissociated DCN neurons from E11 mouse spinal cords were 885 infected with shRNAs, and co-cultured with COS7 cell aggregates expressing Cbln1. Commissural axons were imaged at two time points $(0$ and $22 \mathrm{~h}$ ). Commissural axon turning angles toward the Cbln1-OE cell aggregates and gradients were measured between the colored arrow (red for shCtrl and green for shNrxn2s) at $22 \mathrm{~h}$ and the black arrow at $0 \mathrm{~h}$. Rose plots of axon turning angles are shown to the right for each condition. Angles were clustered in bins of $10^{\circ}$, and the number of axons per bin is represented by the radius of each segment. Orange bins indicate attraction, and blue bins 
A

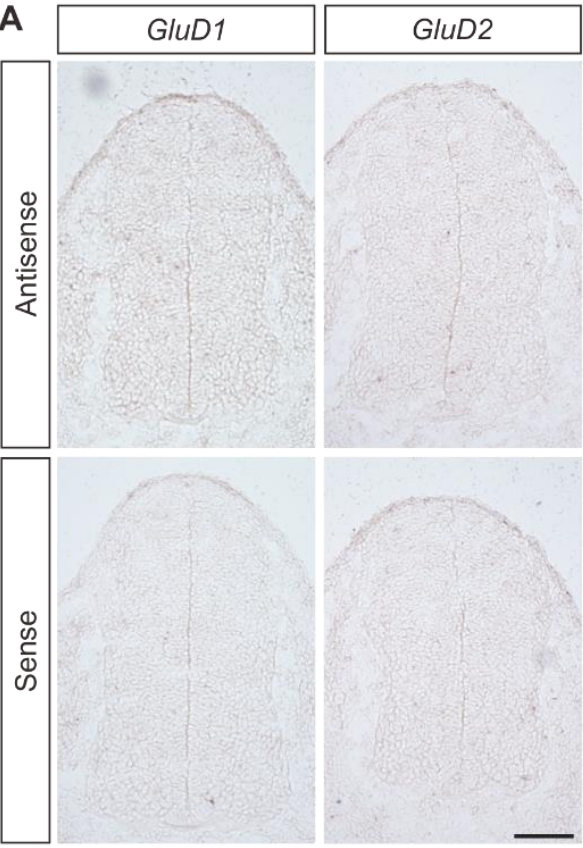

E

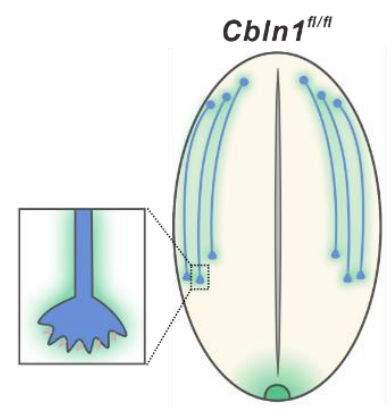

$\mathbf{F}$

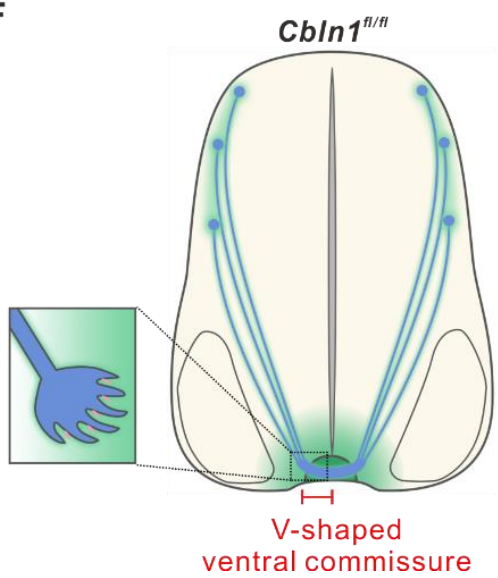

\section{Cbln1 in the developing spinal cord.}

hybridization. Scale bar, $100 \mu \mathrm{m}$.
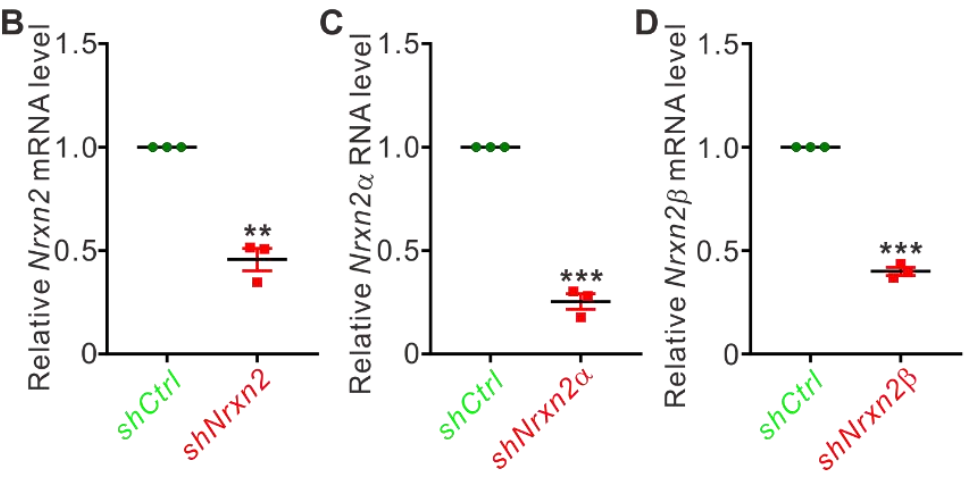

Cbln1

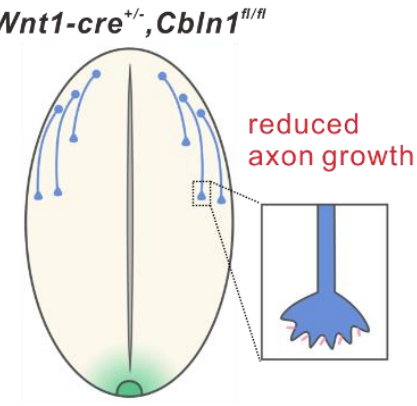

Nrxn2

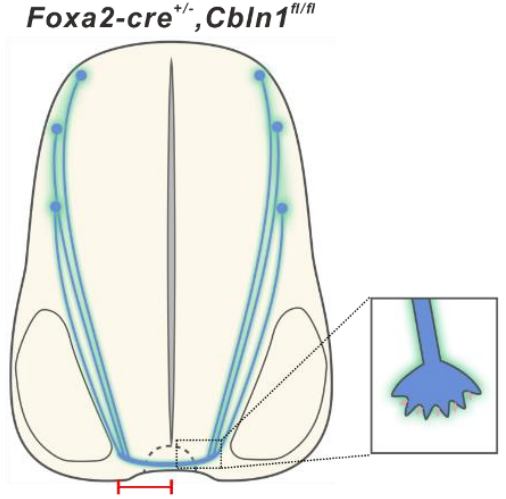

U-shaped and thinner ventral commissure

Figure 5-figure supplement 1 . Working models for cell-autonomous and non-cell-autonomous

(A) GluD1 or GLUD2 mRNA was not detected in E11.5 spinal cord cross-sections by in situ 
898 (B-D) Validation of knockdown by shRNAs. Dissociated cerebellar granule cells from P8 mouse pups

899 were cultured and lentiviral shRNAs were infected. Significant knockdown was achieved by shRNAs against $N r x n 2, N r \times n 2 \alpha$ and $N r x n 2 \beta$, respectively. RT-qPCR data are mean \pm SEM. and represented as dot plots: ${ }^{* *} p=0.0084$ for $(\mathrm{B}) ;{ }^{* *} p=0.00010$ for $(\mathrm{C}) ;{ }^{* *} p=0.00020$ for (D); by unpaired Student's $t$ test.

(E) Working model for the stimulation of commissural axon growth by the cell-autonomous Cbln1. In autocrine manner and binds to Nrxn2 receptors to stimulate commissural axon growth. In the DCNspecific Cbln1 cKO embryos, commissural axon growth is reduced compared with their littermate

908 controls.

909 (F) Working model for the attraction of commissural axon growth toward midline by the non-cell-

910 autonomous, floor plate-derived Cbln1. When commissural axons approach the midline, the floor

911 plate-derived Cbln1 attracts commissural axons to the midline which is also mediate by Nrxn2 receptors. In the floor plate-specific CbIn1 cKO embryos, commissural axon guidance in the midline crossing is impaired, resulting in a U-shaped and thinner ventral commissure compared with the Vshaped and thick ventral commissures in the littermate control embryos. 
bioRxiv preprint doi: https://doi. org/10.1101/2021.11.16.468844 this version posted November 16,2021 . The copyright holder for this preprint (which was not certified by peer review) is the author/funder, who has granted bioRxiv a license to display the preprint in perpetuity. It is made available under aCC-BY 4.0 International license.
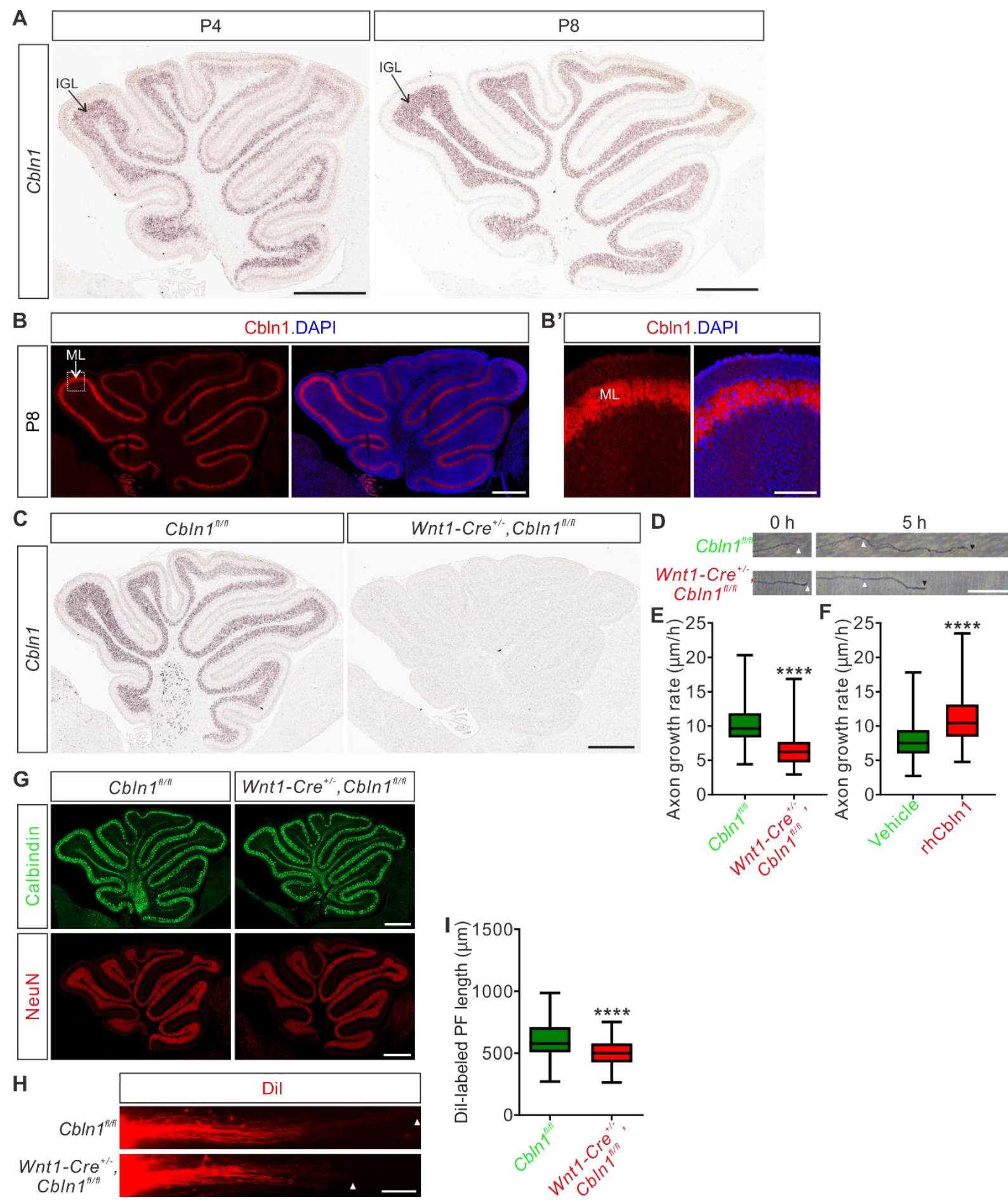

Wnt1-Cre Cbln $1^{t / / f}$

Figure 6. Cell-autonomous Cbln1 is required for cerebellar granule cell axon growth.

918 (A) In situ hybridization of $C b \ln 1$ in cerebella during P4 and P8. Cbln1 mRNA is specifically and highly expressed in granule cells, esp. in the inner granule layer (IGL). Scale bars, $500 \mu \mathrm{m}$. 
(B) High level of Cbln1 protein is detected in the molecular layer (ML) of P8 cerebellum, which is expressed and secreted by granule cell (GC) axons. Higher magnification of the boxed area is shown in ( $\left.\mathbf{B}^{\prime}\right)$. Scale bars, $500 \mu \mathrm{m}(\mathbf{B})$ and $100 \mu \mathrm{m}\left(\mathbf{B}^{\prime}\right)$. axons); ${ }^{* * * *} p=4.05 \mathrm{E}-52$; by unpaired Student's $t$ test. Scale bar, $20 \mu \mathrm{m}$.

930 (F) Extrinsic Cbln1 could stimulate GC axon growth. WT P6 GC neurons were cultured in vitro and rhCbln1 $(500 \mathrm{ng} / \mathrm{ml})$ was added to the culture. Compared with the vehicle control, rhCbln1 significantly enhanced GC axon growth. Data are represented as box and whisker plots: Vehicle $(n=$ 342 axons) vs rhCbln1 ( $n=299$ axons); ${ }^{* * *} p=5.58 \mathrm{E}-32$; by unpaired Student's $t$ test.

(G) Neurogenesis is not disturbed in the Cbln1 cKO cerebellum at P8. Immunostainings of the not affected. Scale bars, $500 \mu \mathrm{m}$.

$938(\mathbf{H}, \mathbf{I})$ Lengths of parallel fibers labeled by Dil were significantly decreased in Cb/n1 cKO mice at P6.

939 The white arrowheads indicate the terminals of Dil-labeled PFs. Quantification of PF lengths is shown 940 as box and whisker plots (I): ${ }^{* * *} p=1.09 \mathrm{E}-13 ; n=190$ axons for $C b / n 1^{f / f l}$ mice, $n=132$ axons for

941 Wnt1-Cre ${ }^{+/}, C b / n 1^{f / f l}$ mice; by unpaired Student's t-test. Scale bar, $100 \mu \mathrm{m}$. 
A
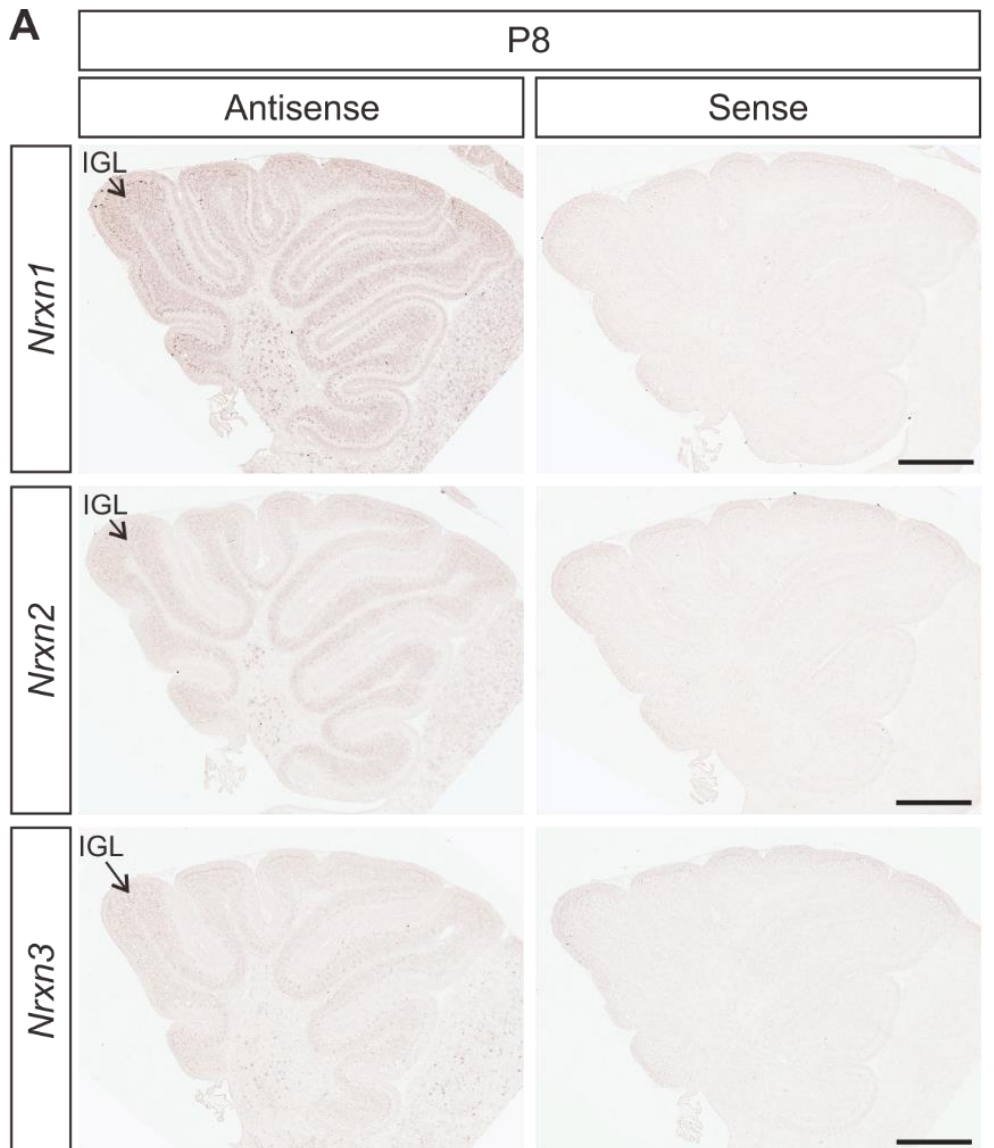

ำ the cerebellum at these stages. Scale bars, $500 \mu \mathrm{m}$.

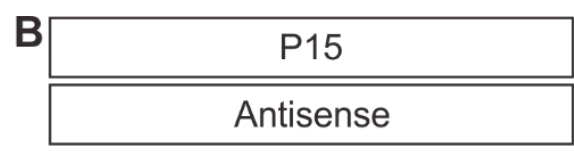

IGL

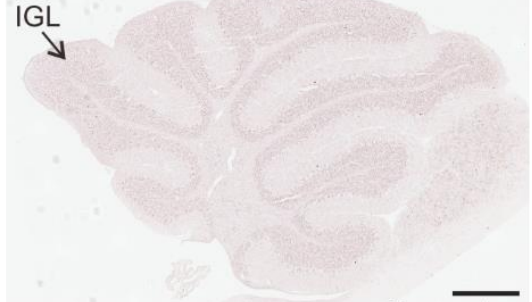

IGL

$\searrow$

IGL

$\searrow$

PC

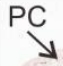

5 (B).

Nrxn1, Nrxn2 and Nrxn3 mRNAs were detected in the inner granule layer (IGL). GluD2 mRNA was

highly and specifically expressed in the Purkinje cells (PCs) while GluD1 mRNA was not detected in 
bioRxiv preprint doi: https://doi.org/10.1101/2021.11.16.46884- this version posted November 16,2021 . The copyright holder for this preprint (which was not certified by peer review) is the author/funder, who has granted bioRxiv a license to display the preprint in perpetuity. It is made available under aCC-BY 4.0 International license.
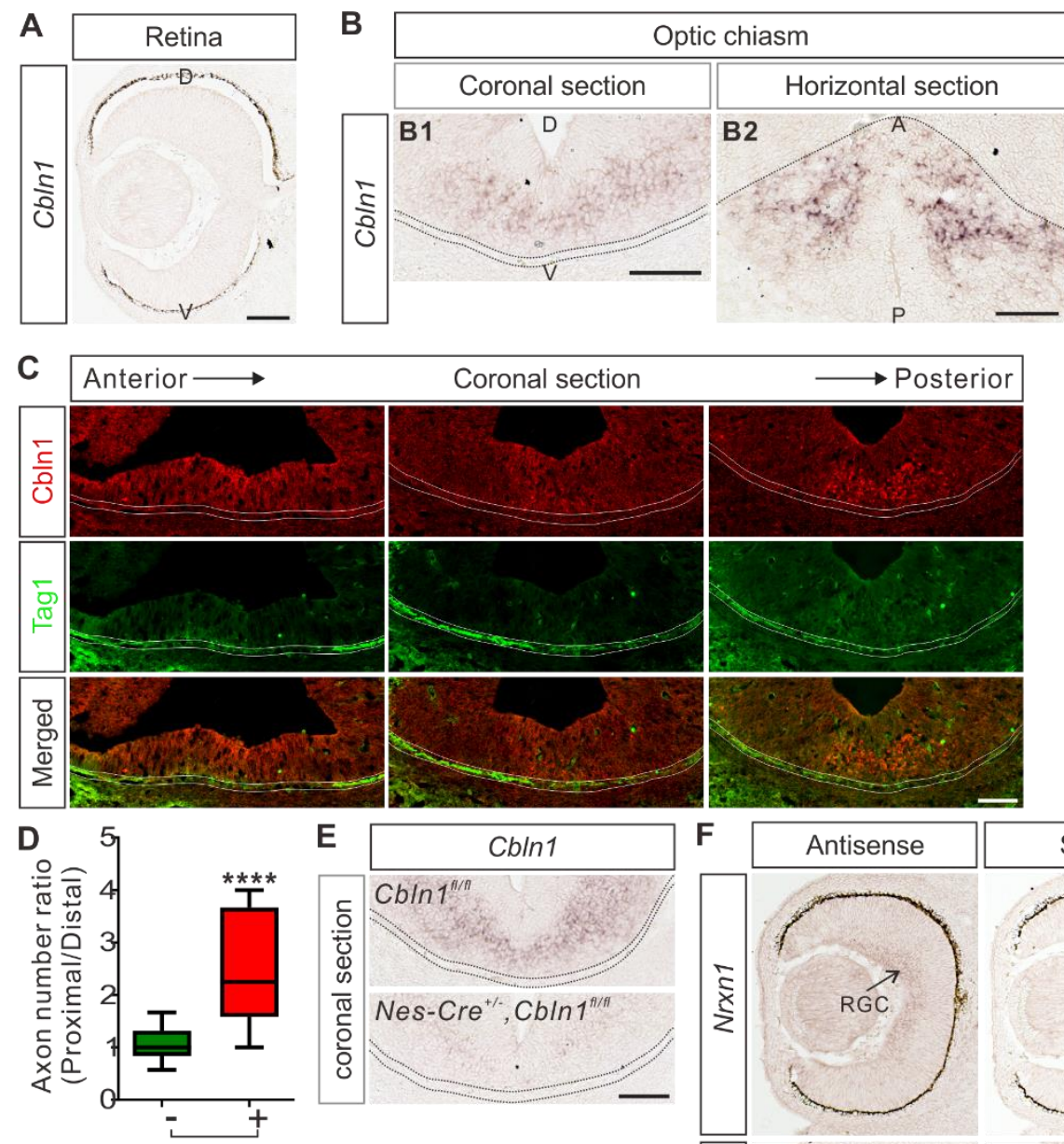

of Cbln1-FLAG

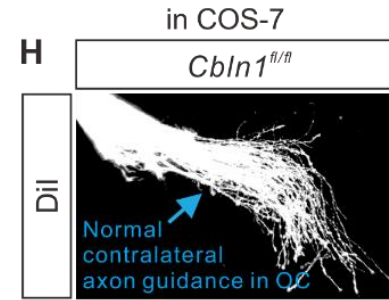
Nes-Cre ${ }^{+/}, \mathrm{Cb}_{\ln 1^{f / \pi}}$


Figure 7. Non-cell-autonomous Cbln1 regulates RGC axon guidance in optic chiasm.

(A) In situ hybridization of $C b / n 1$ in the developing retina. Cbln1 mRNA expression was not detected

in the retina of E13 mouse embryos. D, dorsal; V, ventral. Scale bar, $100 \mu \mathrm{m}$. 
(B) In situ hybridization of Cbln1 in E13 mouse brain sections (coronal section for B1; horizontal

955

956

957

958

959

960

961

962

963

964

965

966

967

968

969

970

971

972

973

974

975

976

977

978

979

section for B2). Cbln1 mRNA expression was detected in the floor of the third ventricle, adjacent to

the optic chiasm. The dotted lines indicate the boundary of the optic chiasm. D, dorsal; V, ventral; A, anterior; P, posterior. Scale bars, $100 \mu \mathrm{m}$.

(C) Immunostaining of Cbln1 in coronal brain sections from E13 mouse embryos. Cbln1 protein was detected in the floor of the third ventricle, adjacent to the optic chiasm. Tag1-marked RGC axons projected to the optic chiasm are outlined by the dotted lines. Serial sections from anterior level to posterior level were shown. Scale bar, $100 \mu \mathrm{m}$.

(D) Extrinsic Cbln1 attracted RGC turning in vitro. Retina explants from E13 mouse embryos were cocultured with COS7 cell aggregates expressing CbIn1-FLAG with GFP or GFP alone. Quantification of RGC axon turning was performed by measuring the axon number ratio (proximal/distal), similarly as CA axon guidance assay. Data are represented as box and whisker plots: $\mathrm{Ctrl}$ ( $n=17$ explants) vs OE ( $n=9$ explants), ${ }^{* * * *} p=5.62 \mathrm{E}-05 ;$ by unpaired Student's $t$ test.

(E) Ablation of $\mathrm{Cbln} 1$ in Nes-Cre $e^{+/}, \mathrm{Cbln} 1^{f l / f l}$ cKO mouse embryos was confirmed by in situ hybridization of E13 coronal brain sections. The dotted lines indicate the boundary of the optic chiasm. Scale bar, $100 \mu \mathrm{m}$.

(F) In situ hybridization of Nrxn1 and Nrxn2 in E13 retina. Nrxn1 and Nrxn2 mRNAs were detected in retinal ganglion cells (RGC). Scale bar, $100 \mu \mathrm{m}$.

(G) Immunostaining of Nrxn2 in E13 retina. Nrxn2 is expressed only in the contralateral RGCs marked by Brn3a. Scale bar, $100 \mu \mathrm{m}$.

$(\mathrm{H}, \mathrm{I})$ Axon guidance defects in the optic chiasm (OC) of Cbln1 cKO embryos. Dil tracing of RGC axons was performed to visualize axon trajectory in OC. Compared with normal axon attraction of contralateral RGCs in OC of control embryos, Cbln1 cKO embryos showed reduced axon attraction to OC. The phenotype is illustrated in (I). Scale bar, $100 \mu \mathrm{m}$.

(J, K) RGC central targeting defects of Cbln1 cKO mice. Representative images of coronal sections through the LGN (lateral geniculate nucleus) after unilateral injection of CTB-Alexa Fluor 555 at P4 in 
bioRxiv preprint doi: https://doi org/10.1101/2021.11.16.468844; this version posted November 16, 2021. The copyright holder for this preprint (which was not certified by peer review) is the author/funder, who has granted bioRxiv a license to display the preprint in perpetuity. It is made available under aCC-BY 4.0 International license.

See the separate Excel data set

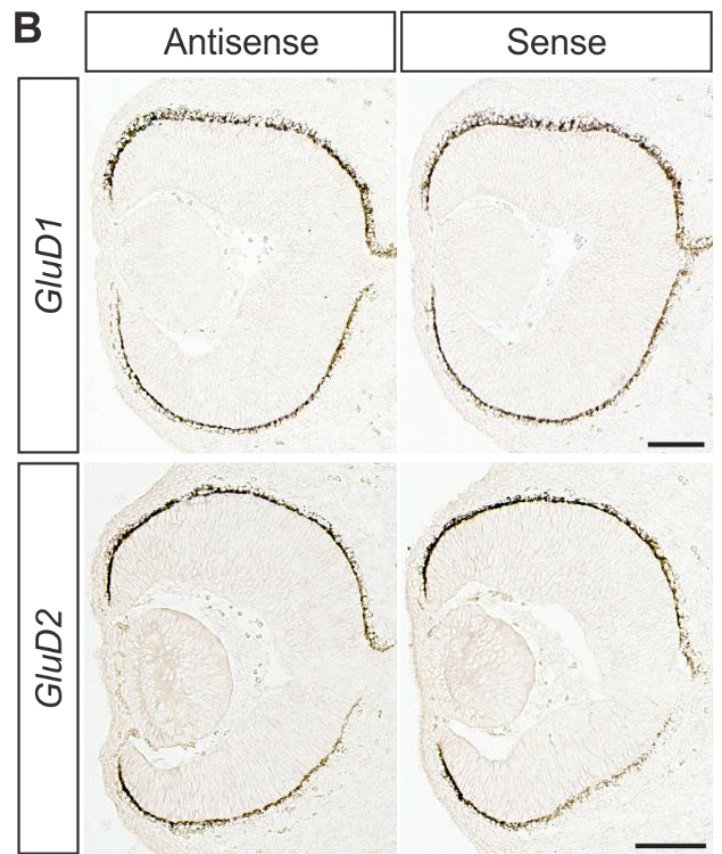

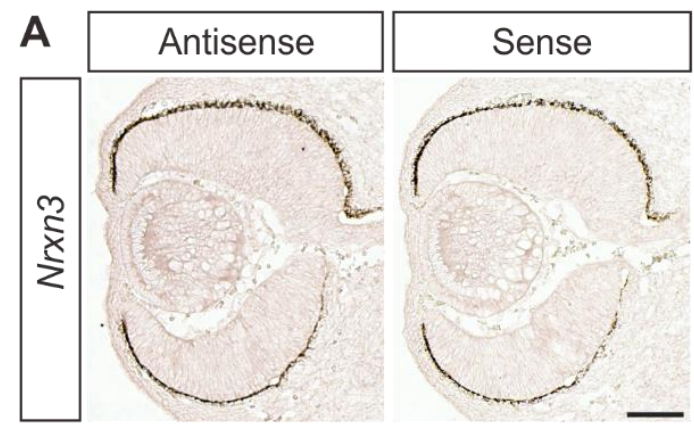

Figure 7-figure supplement 1. In situ hybridization of Cbln1 receptors in the developing retina. GluD2 mRNA was not detected in the developing retina. Scale bars, $100 \mu \mathrm{m}$. 